\title{
INVERSIÓN ECONÓMICA Y GESTIÓN PATRIMONIAL PARTICULAR ENTRE LOS PREBENDADOS DE LA ESPAÑA MODERNA: CÓRDOBA (1500-1800) ${ }^{1}$
}

\author{
Antonio J. DíAz RodRíGuez \\ Universidad de Córdoba
}

\begin{abstract}
Resumen: Se pretende a través de este artículo dar a conocer un aspecto algo descuidado tanto por la historia social como por la historia económica, el análisis de los ingresos de las élites eclesiásticas locales, elemento financiero significativo en el entorno familiar, urbano y regional. Para ello se parte del caso de la ciudad andaluza de Córdoba como objeto de estudio en el marco de la España moderna.
\end{abstract}

Palabras clave: eclesiásticos, cabildos, gestión financiera, bienes inmuebles, préstamo.

Abstract: It is tried through this paper to present a somewhat neglected aspect by both social history and economic history, the income analysis of local ecclesiastical elites, a significant financial element in the family, urban and regional environment. It starts from the case of the andalusian city of Cordoba as object of study in the context of Early Modern Spain.

Key words: ecclesiastics, cathedral chapters, economic management, real estate, loan.

Recibido: 22 marzo 2011 Aceptado: 20 julio 2011

1 La elaboración de este trabajo ha sido posible gracias al disfrute de una beca del Ministerio de Educación y Ciencia (Ref. AP2006-03588). A lo largo del artículo se emplean las siguientes abreviaturas en las referencias a fuentes de archivo: ACCo (Archivo de la Catedral de Córdoba), AGS (Archivo General de Simancas), AHPCo (Archivo Histórico Provincial de Córdoba), ARChGr (Archivo de la Real Chancillería de Granada), ARChV (Archivo de la Real Chancillería de Valladolid) y SN (Sección Nobleza del Archivo Histórico Nacional). 
Élite eclesiástica urbana de la Monarquía Hispánica, los cabildos catedralicios, en tanto que instituciones, han sido objeto de estudio por la historiografía española desde hace décadas ${ }^{2}$, con un interés significativo hacia lo económico ${ }^{3}$, aspecto en que no cabe decir lo mismo con respecto al grupo humano que los conformó ${ }^{4}$. Disponemos de aportaciones generales de enorme valor desde las perspectivas de la historia social y de la familia -me limitaré a mencionar obras como las de Antonio Irigoyen López, Antonio Cabeza Rodríguez o María Teresa Benito Aguado5-, pero

2 Un balance historiográfico general en DÍAZ RODRÍGUEZ, A. J.: "Cabildos eclesiásticos y clero catedralicio en el Antiguo Régimen: estado de la cuestión”, Revista de Historiografía, 13, 2010, pp. 82-99.

3 Aportaciones ya clásicas sobre el tema para época moderna son las de BURGO LÓPEZ, C.: "La estructura económica del cabildo de Lugo a finales del siglo XVIII", Obradoiro de Historia Moderna, 2, 1993, pp. 65-84. CASADO ALONSO, H.: La propiedad eclesiástica en la ciudad de Burgos en el siglo XV. El cabildo catedralicio, Valladolid, Universidad de Valladolid, 1980; FERNÁNDEZ FLORES, J. A.: El patrimonio del cabildo catedralicio de León en la segunda mitad del siglo XV, Valladolid, Secretariado de Publicaciones de la Universidad de Valladolid, 1985; GARCÍA FIGUEROLA, L. C.: La economía del cabildo salmantino del siglo XVIII, Salamanca, Ediciones Universidad de Salamanca y Junta de Castilla y León, 1989; o MOYA ULLDEMOLINS, J. M.: “Aspectos económicos de la Mesa Capitular del cabildo de la catedral de Córdoba", en Actas del I Congreso de Historia de Andalucía. Andalucía Moderna (siglos XVI y XVII), Córdoba, Monte de Piedad y Caja de Ahorros de Córdoba, 1978, t. II, pp. 243-254. Más recientes son, entre otras obras, las de GONZÁLEZ MARISCAL, M.: "Propiedades y rentas territoriales del cabildo de la catedral de Sevilla, 1524-1606. Primeros resultados y reflexiones", en LLOPIS AGELÁN, E. et alii (coords.), Renta de la tierra, comercio, mercados y consumo de productos agrarios, siglos XIIIXIX. VIII Congreso de la Asociación Española de Historia Económica, Santiago de Compostela, 2005, pp. 1-36 (versión digital); LÓPEZ ESTUDILLO, A.: "La mesa capitular de la catedral de Córdoba y la gestión de su patrimonio rústico (1700-1840)", en ROBLEDO, R. (ed.), Actas del VIII Congreso de la Asociación Española de Historia Económica (Santiago de Compostela, 13-16 de septiembre de 2005), Zaragoza, 2005, pp. 1-20 (versión digital); VÁZQUEZ LESMES, R.: "El cabildo catedralicio cordobés y su aportación económica a la nueva dinastía en la Guerra de Sucesión”, en CONTRERAS CONTRERAS, J., ALVAR EZQUERRA, A. y RUIZ RODRÍGUEZ, J. I. (coords.), Politica y cultura en la época moderna: (cambios dinásticos, milenarismos, mesianismos y utopías), Madrid, Universidad de Alcalá de Henares, 2004, pp. 327-336: o del mismo autor: «Obras pías, censos y endeudamientos de la nobleza en los siglos XVII y XVIII: el caso del cabildo catedralicio cordobés», en VÁZQUEZ LESMES, R. (coord.), Homenaje a Antonio Domínguez Ortiz, Córdoba, Real Academia de Córdoba, Córdoba, 2004, pp. 179-208. Muchas quedan en el tintero, pero no pretende ser éste un estado detallado de la cuestión, que ocuparía per se más espacio del que aquí dispongo.

4 Algo se ha hecho ya no obstante en esta línea. Desde un punto de vista más institucional véase: LATORRE CIRIA, J. M.: Economía y religión: las rentas de la catedral de Huesca y su distribución social (siglos XVI-XVIII), Zaragoza, Institución «Fernando el Católico», 1992. De valor tanto en lo económico como en lo social es: CABEZA RODRÍGUEZ, A.: "Ingresos percibidos por los eclesiásticos de la catedral de Palencia durante la época Moderna. Operaciones efectuadas en torno al reparto de prebendas", en Actas del II Congreso de Historia de Palencia, Diputación Provincial de Palencia, Palencia, 1990, t. III, pp. 483498. Un interesante punto sobre el que bastante se ha especulado pero poco se ha profundizado es el relativo a la función crediticia de cabildos y prebendados. Sobre ello puede verse: QUINTANA ANDRÉS, P. C.: "Las instituciones religiosas y el crédito privado durante el Antiguo Régimen: Los censos al quitar del cabildo catedral de Canarias", Boletín Millares Carlo, 16, 1998, pp. 217-243.

5 IRIGOYEN LÓPEZ, A.: Entre el cielo y la tierra, entre la familia y la institución: el cabildo de la catedral de Murcia en el siglo XVII, Murcia, Servicio de Publicaciones de la Universidad de Murcia, 2001. CABEZA RODRÍGUEZ, A.: Clérigos y señores. Política y religión en Palencia en el Siglo de Oro, 
en líneas generales puede afirmarse que la gestión patrimonial entre los prebendados es un campo del que queda mucho por explorar 6 .

El caso cordobés cuenta además con una clara ventaja: se trata de un término medio entre los cabildos españoles. Por encima, económicamente, de otros cabildos como el de Jaén y justamente por debajo de corporaciones catedralicias del poderío de las de Sevilla o Toledo, por citar algunos ejemplos.

A lo largo de las siguientes páginas me centraré en examinar, en la medida en que las limitaciones físicas de un artículo lo permitan, una de las caras de la realidad financiera de estos eclesiásticos, a partir del caso cordobés: el examen de sus actividades económicas privadas y de la administración de sus rentas particulares en lo que a los ingresos concierne. Queda pues fuera de las ambiciones de este artículo una cuestión tan interesante como el análisis del gasto, lo que nos llevaría a hablar de la financiación de las estrategias familiares, por ejemplo, aspecto merecedor de un espacio propio. No es tampoco objetivo de este trabajo el estudio de la composición de la prebenda o sus fuentes, sino el bosquejo de toda la actividad económica paralela que caracterizó a este grupo de élite.

\section{El origen de los ingresos}

Lo antes dicho no obsta, obviamente, para que a continuación tratemos de situar, de manera sucinta, los orígenes de los ingresos de cuya gestión particular hablaremos y de los que la prebenda fue, mayoritariamente, fuente principal, aunque no única, como se verá.

Las prebendas componen una categoría propia dentro del sistema beneficial, si bien se rigen a la mayoría de los efectos por los mismo cánones que los beneficios no consistoriales. Toda prebenda era una renta procedente del usufructo de bienes y derechos de una mesa capitular (porción del diezmo correspondiente a la misma, fincas rústicas e inmuebles urbanos en arrendamiento, explotación de monopolios y privilegios, etc.) cuyos beneficiarios eran los miembros del cabildo eclesiástico en cuestión: dignidades, canónigos y racioneros.

Dado que cada una de estas instituciones colegiadas mantenía su propia ordenación jurídica y organización económica dentro de unas normas generales, habla-

Palencia, Excma. Diputación Provincial de Palencia, 1996. BENITO AGUADO, Ma T.: La sociedad vitoriana en el siglo XVIII: el clero, espectador y protagonista, Bilbao, Servicio Editorial de la Universidad del País Vasco, 2001.

6 Resulta muy esclarecedora para la historiografía económica sobre el clero REY CASTELAO, O.: "Las economías eclesiásticas en la Edad Moderna: un estado de la cuestión de la historiografía reciente (1994-2006)", en CORTÉS PEÑA, A. L. y LÓPEZ-GUADALUPE MUÑOZ, M. L. (eds.), La Iglesia española en la Edad Moderna. Balance historiográfico y perspectivas, Madrid, Abada, 2007, pp. 179-221. 
mos de un mundo dominado por los particularismos ${ }^{7}$. Heterogeneidad y complejidad fueron los rasgos distintivos de las finanzas capitulares. Por otro lado, la prebenda nunca equivalió a una cantidad exacta en moneda de cuenta, algo fijo e invariable. Su mismo origen, ligado a la producción agraria, sobre todo cerealística, y sus fluctuaciones, hizo eso de todo punto imposible. El prebendado cobraba una cierta cantidad en metálico, pero el grueso venía dado en especie: trigo, cebada, gallinas, aceite, vino... Como ya señaló el profesor José Manuel Latorre, no es fácil llegar a conocer el rendimiento exacto de las prebendas, sobre todo por la escasez y el carácter incompleto de las fuentes ${ }^{8}$. No obstante, a modo de orientación, cabe ofrecer una aproximación al valor de las prebendas de la catedral de Córdoba.

Se componía el cabildo cordobés de 58 prebendas: 8 dignidades, 20 canonjías, 10 raciones enteras y 20 medias raciones por orden decreciente de importancia. El valor de una ración entera oscilaba en la primera mitad del XVII entre los $12.000 \mathrm{y}$ los 15.000 reales anuales y el de una media ración entre los 6.000 y los 7.500 reales. Mayores divergencias se daban entre las canonjías, dada las grandes diferencias de ingresos que había entre los distintos préstamos anexos a cada una. Grosso modo puede decirse que para estos mismos años eran bastante habituales valores entre los 17.000 y los 22.000 reales anuales. Igualmente dispares eran los valores de las dignidades. Por lo general, los capitulares que las ocuparon poseyeron asimismo otra prebenda. Lo que en conjunto venían a cobrar para las fechas indicadas se movía entre los más de dos mil y los tres mil ducados al año, cifra que podían llegar a superar las dignidades más ricas, caso de los arcedianatos, cobrando entre 34.000 y 36.000 reales.

La renta de una misma prebenda podía sufrir oscilaciones interanuales considerables, además. Así, a lo largo de ocho años disfrutando del mismo préstamo y cumpliendo por igual con sus obligaciones, la canonjía de don Fernando Gazapo, magistral de la catedral de Córdoba, conoció valores desde los 18.990,4 reales de 1655 hasta los 23.980,3 de 1660, pasando por cifras intermedias como los 21.860 de 1661 o los $21.433,5$ de $1662^{9}$.

A principios del Seiscientos, un forastero daba los siguientes apuntes sobre la catedral y sus prebendas a su paso por la ciudad andaluza:

Ay ocho dignidades y veinte canonjías, que cada una pasa de dos mil ducados de renta, las quales tienen ciertos anejos, que se ban optando por sus antigüedades, con los quales algunas suelen valer dos o tres mil ducados. Ay diez raciones

7 BARRIO GOZALO, M.: El sistema beneficial de la Iglesia española en el Antiguo Régimen (1475-1834), Alicante, Universidad de Alicante, 2010, p. 49.

8 LATORRE CIRIA, J. M.: op. cit., pp. 299-300.

9 ACCo, Mesa capitular, caja 3.159, doc. 1. 
enteras, que renta cada una mil y ducientos ducados. Ay veinte medias raciones, que vale cada una seiscientos ducados ${ }^{10}$.

Sus ponderaciones eran desde luego optimistas, si bien muy orientativas y no demasiado exageradas, a mi juicio.

Empero, la capacidad financiera que a grandes rasgos caracterizaría al capitular cordobés no sólo tuvo su origen en la prebenda, aunque ésta se erigiera por lo general en la fuente primordial. De ahí que no pueda establecerse un paralelismo absoluto entre el estatus socioeconómico de los individuos y su posición en la jerarquía capitular. Ésta resultó naturalmente un potente condicionante, pero no el único. Salvo para los menos afortunados, el patrimonio heredado constituyó una base de partida importante en este sector del clero, ya fuera en forma de legítima ya como usufructuario de patronatos y capellanías de sangre. La acumulación de beneficios, el desempeño paralelo de otros cargos y oficios, así como un abanico de actividades pecuniarias de corte inversor, prestatario o gestor vinieron a engrosar los ingresos, sustentando las consabidas expectativas de herencia de los parientes ${ }^{11}$.

La posesión junto con la prebenda de uno o varios beneficios con o sin cura de almas fue una tendencia absolutamente generalizada en toda Europa más allá de los casos canónicamente compatibles, como demuestra la documentación vaticana. Por lo común se trataba de capellanías o beneficios simples no servideros, aunque tampoco era inusual la concentración en una misma persona de varias prebendas del mismo o de varios cabildos, especialmente con anterioridad a Trento.

En segundo lugar, junto con los ingresos devenidos del disfrute de otros beneficios eclesiásticos distintos a la prebenda, una parte de los miembros del cabildo fungieron como cargos al servicio de la Corona o de la Santa Sede. Por fuerza, los gajes y emolumentos derivados de la condición de inquisidor, protonotario, oidor, sumiller de cortina del rey o camarero del papa han de ser tenidos en cuenta a la hora de valorar la capacidad económica y financiadora de cada sujeto, sin olvidar que los servicios a los soberanos solían ser recompensados con la concesión de beneficios eclesiásticos, en lo que fue tendencia general de las monarquías europeas ${ }^{12}$. El ingreso

10 JAMMES, J.: La obra poética de Don Luis de Góngora y Argote, Madrid, Castalia, 1987, p. 14 (de un manuscrito de la BNM, editado en un artículo de 1915 de la Revue Hispanique citado en nota a pie de página).

$11 C f$. SORIA MESA, E.: La nobleza en la España moderna. Cambio y continuidad, Madrid, Marcial Pons, 2007, p. 156.

12 «Ainsi le roi, en utilisant des prélats s'appuie sur de techniciens qui lui sont indispensables, élargit la réserve de ses serviteurs naturels, les courtisans, et réalise une économie en utilisant les richesses de l'Église pour les récompenser. La maîtrise royale de la distribution des bénefices représente donc une manne énorme qui joue, dans le financement de l'État, un rôle qui mérite d'être étudié avec précision». MICHON, C.: La crosse et le sceptre. Les prélats d'État sous François Ier et Henri VIII, Paris, Tallandier, 2008 , p. 241. 
en el cuerpo capitular terminaba por vincular a algunos hombres a este cursus honorum, y viceversa. La naturaleza de raciones y canonjías las hacía encajar muy bien en esta amalgama que eran los entramados de poder del Antiguo Régimen, lo cual no las eximió de convertirse en una más de las causas de las fricciones inmanentes al propio sistema. Los incontables procesos judiciales en España y Roma entre consejos y cabildos de la Monarquía son buena muestra de ello, y es probable que haya sido el Santo Oficio en sus dos primeras centurias de existencia el mayor agente de estos choques.

Más allá de una exitosa carrera curial, cortesana o administrativa, que sólo llegó a desempeñar una minoría de los capitulares ${ }^{13}$, las ricas rentas eclesiásticas permitieron la inversión en una serie de campos comunes a todos ellos. A menudo se trató de estrategias económicas desarrolladas por varios miembros de una misma familia a lo largo de décadas. Naturalmente, objetivo principal, que no el único, fue la obtención de nuevas rentas, dinero líquido y seguro que retroalimentase el sistema. El dinero llamó al dinero y la liquidez a una mayor capacidad financiera que se revelaría fundamental.

\section{La inversión en bienes raíces}

La adquisición de inmuebles rústicos y urbanos para su explotación, generalmente por arrendamiento, fue la más característica y conocida de estas inversiones entre el clero catedralicio hispano.

Frente a lo señalado por autores como Loupès para algunas zonas de Francia ${ }^{14}$, no puede concluirse que al menos para Castilla los prebendados se decantaran de forma clara por las fincas rústicas frente a las urbanas. Si bien el fiel de la balanza parece inclinarse hacia las primeras, en efecto más rentables en varios sentidos, la matización es necesaria, puesto que la formación de un patrimonio urbano no dejó de ser objetivo destacado, y así lo refleja la mayoría de los vínculos fundados para los herederos. La posesión de viviendas y tiendas en la ciudad supuso en fin una parte

13 Sobre una base de 700 individuos, un 10\% tuvo ingresos conocidos derivados del desempeño de oficios en la administración del Estado, la docencia universitaria, o al servicio directo de los reyes, si descontamos las capellanías reales, que a estos efectos he preferido computar como un beneficio eclesiástico más. Sí se han incluido los cargos inquisitoriales asalariados (juez, fiscal, secretario, etc.). Sólo en torno al 3\% (un 2,85\% para ser más exactos) disfrutó de ingresos por oficios curiales o de la corte pontificia (cubicularios, auditores de la Rota romana, escritores y protonotarios apostólicos...), si no tenemos en cuenta a todos aquellos cardenales y familiares del papa dedicados a la acumulación de beneficios, cuya inclusión no haría sino distorsionar la imagen.

14 «Les maisons urbaines ne les attirent qu'assez peu, tandis que le propriétés foncières à la campagne ont tout leur faveur». LOUPÈS, Ph.: Chapitres \& chanoines de Guyenne aux XVIIe et XVIIIe siècles, Paris, Éditions de l'École des Hautes Études en Sciences Sociales, 1985, p. 293. 
importante del patrimonio personal y de su arrendamiento devino para los ingresos brutos anuales un porcentaje que, en líneas generales, tiende a incrementarse conforme se desciende en la jerarquía capitular.

Sí existió, en cuanto a inversiones agrarias se refiere, una clara preferencia por la compra de pequeñas explotaciones de regadío, viña y olivar, muy por encima de las de tipo cerealístico. Desde las faldas de la sierra a la fértil campiña, las numerosas huertas y lagares ofrecían un más cómodo acceso al mercado de la tierra que las grandes extensiones de secano así como a la propiedad de retiros campestres en las proximidades de la ciudad. El aumento de los precios del vino y del aceite en Andalucía occidenta ${ }^{15}$ y los intentos de diversificación de los ingresos de origen agrario habrían también de ser tenidos en cuenta. Estas propiedades albergaban a menudo, junto a casas de campo, instalaciones como lagares, almazaras y bodegas, de lo que se derivaba por tanto una presencia en el mercado local, aún más patente en aquellos que junto a los medios de producción y transformación disponían de medios para el acceso directo a la venta. Tal fue el caso en el sector vitivinícola, controlado en buena medida por los llamados clérigos lagareros ${ }^{16}$. La producción se complementaba con

15 En relación con los precios de 1511, a mediados del XVI la fanega de trigo dobló su valor mientras que la arroba de aceite prácticamente lo triplicó y la de vino lo multiplicó por 7,5. Cf. CARANDE, R.: op. cit., pp. 53-54.

16 Así se refiere a ellos el informe de la visita secreta al obispado de Córdoba de 1638, solicitándose «que no midan ellos el vino, ni tengan mujer, ni den de comer alcaparrones y pimientos ni asientos; tengan postigo fuera de casa si puede ser, que parece mal el quartillo en las manos en que poco antes estuvo el Stmo. Sacramento, y advierte que venden algunos a lo honrado, y laban sus manos de acciones viles» (Cf. COBOS RUIZ DE ADANA, J.: El clero en el siglo XVII (estudio de una visita secreta a la ciudad de Córdoba), Córdoba, Escudero, 1976, p. 170). Un porcentaje considerable disponía entre sus posesiones tanto de viñas y lagares como de bodegas y tiendas, lo que les capacitaba para obviar intermediarios, y en tanto que eclesiásticos, disfrutaban de exención fiscal en la entrada de vino a la ciudad por estar dedicado teóricamente al culto divino. Dolo y logro parecían puestos en bandeja y en la abundantísima documentación de pleitos, quejas y denuncias tenemos el escaparate del aprovechamiento de tales circunstancias. Había entre los prebendados quien daba tabernas o mesones de su propiedad en alquiler, condicionado a la venta exclusiva de los vinos producidos por el propietario y no de otro productores. Así se expresa por ejemplo en el contrato por una tienda que don Pedro González de Heredia tenía en al calle de la Herrería con precio de renta anual de 296 reales y 17 pares de gallinas, dado el 4 de noviembre de 1632 (AHPCo, leg. 11.749-P, fols. 893r.-v.). Seis años más tarde fue acusado ante el obispo como tratante dedicado a la venta de carbón y de vino de su lagar por las tabernas (COBOS RUIZ DE ADANA, J.: op. cit., p. 168). Otros propietarios de estos establecimientos fueron, por citar algunos, el tesorero don Jerónimo de Corral, dueño a fines del XVI de una taberna arrendada al racionero Juan de Riaza (SN, Luque, caja 124, doc. 17, fol. 19r.), o el chantre don Sebastián de Arias, cuyo mesón de los Carros en la ribera le reportaba unos 750 reales anuales a mitad del siglo XVIII (AHPCo, Catastro de Ensenada, libro 323, fols. 453v.-466r.). Difícil era desligar el consumo de vino del ámbito lúdico más oscuro, y no fue raro que muchos de estos espacios ocultaran garitos de juego y aun de prostitución, a la búsqueda de mayores beneficios. En la mencionada visita del obispo Pimentel, la dedicación a estos negocios es una de las dos acusaciones más comunes, «que hay casas de clérigos donde dan de comer y juegan, y en otras admiten mugeres y hombres que no ofendieran a Dios si les faltara esta comodidad» (COBOS RUIZ DE ADANA, J.: op. cit., p. 172). Así resultan denunciados varios prebendados: el racionero Luis de Castillejo, que «vende vino en su casa de 
otras actividades como la apicultura ${ }^{17}$, la cría de pequeños hatos ${ }^{18}$ o el cuidado de moreras $^{19}$, que a su vez permitía sacar partido a las tierras de peor calidad.

En menor medida, es también propietario de grandes extensiones de cultivo de secano y dehesas para el ganado ${ }^{20}$, así como de cabañas ganaderas de cierta

un lagar que tiene» (Ibidem, p. 164), el canónigo Juan Ruiz de Quintana, quien hace otro tanto, «no en su casa, sino en una taberna donde está una moza muy vellaca y deshonesta y se recogen allí otras» (Ibidem, p. 165), el racionero medio don Juan Cabrera de Briones, que «tiene un lagar, vende vino en su casa en un apartado ha do juegan y guisan» (Ibidem, p. 167), etc.

17 La quinta parte de los capitulares residentes en Córdoba que aparecen recogidos en el Catastro de Ensenada para el término de Córdoba señala entre sus bienes la posesión de colmenas: veinticuatro don Juan Manuel de Samaniego, diecisiete don Francisco Fernández de Córdoba, veintidós don Juan Morillo Velarde, o las treinta siete de don José de Medina y Requejo (AHPCo, Catastro de Ensenada, libro, fols.). Un siglo antes, don Pedro González de Heredia entregaba durante tres años a un mismo apicultor la explotación de ochenta colmenas, situadas por mitad en dos posadas de abejas diferentes, por 330 reales y dos arrobas de la mejor miel al año (AHPCo, leg. 11.767-P, fols. 94r.-v.). Doce de ellas por cierto no eran de su propiedad, sino que las había tomado en arrendamiento junto con la huerta y lagar en que estaban de las hijas huérfanas del licenciado Lucas de Carrasquilla, en condiciones bastante beneficiosas para él por ocho años (AHPCo, leg. 11.766-P, fols. 1.261r.-1.262v.).

18 Además de varias bestias para el desempeño de las labores, normalmente se mantienen algunas cabras y vacas en número menor a la veintena. Don Antonio de Castillejo y Velasco declara ser propietario de cinco asnos y diecinueve vacas, don José de Medina Requejo de seis cabezas de ganado vacuno en el término de Córdoba; don Juan Manuel de Samaniego de dos mulas y catorce cabezas de ganado bovino; don Luis Beltrán de Guevara de dieciocho vacas, cincuenta cerdos y otros diez animales entre yeguas, jumentos y pollinos... AHPCo, Catastro de Ensenada, libro 323, fol. 469r., libro 324, fols. 937v.-938r. y 938r.-943v., y libro 328, fols. 47v.-48v.

19 La morera (morus alba) era un árbol prácticamente omnipresente en las huertas y cortijos de Córdoba. Además de un magnífico forraje para el ganado, especialmente el porcino, era el eje sobre el que orbitaba la sericultura local, al ser sus hojas el único alimento del gusano de seda. La relativa importancia de la industria sedera cordobesa, siempre deficitaria de materia prima, ha sido destacada por varios autores (Cf. FORTEA, J. I.: op. cit., pp. 312-334, y a partir de él ZOFÍO LLORENTE, J. C.: "La industria en España durante los siglos XVI y XVII", en ALVAR EZQUERRA, A., et alii, La economía en la España moderna, Madrid, Istmo, 2006, pp. 336-338). A mediados del XVIII, su aprovechamiento podía suponer aún un porcentaje no despreciable de la utilidad teórica del terreno: de las algo más de veintidós fanegas de regadío de primera calidad que poseía el racionero Sabariego en la Huerta de los Reales Alcázares, arrendadas por 4.000 reales, la fanega y media dedicada a moredal tenía un valor anual de 420 , esto es, un $10,5 \%$. En la misma fecha, a las tres fanegas y tres celemines de moreras de la casa de campo de don Fernando de Loaísa se le calculaban una utilidad anual de 630 reales, lo que equivalía al 21,3\% del de la totalidad de la finca. AHPCo, Catastro de Ensenada, libro 323, fols. 440v.- 449v., y libro 325, fols. 223r.-240v.

20 Los mayores terratenientes del cabildo abundaron sobre todo entre fines del XV y fines del XVI. Suelen ser, bien hijos de los principales linajes de la ciudad que llevan como parte de su herencia grandes cortijos, bien dignidades con ingresos tan elevados que les permiten la compra de este tipo de fincas, o ambas cosas a la vez. Concretamente entre los propietarios de dehesas del XVI podría citarse al arcediano don Francisco de Simancas, en cuya finca pastaban cerca de un centenar de cabezas de ganado vacuno y una docena de caballos además de algún otro animal. Gran terrateniente fue el deán don Juan de Córdoba, a la partición testamentaria de su padre el conde de Cabra contribuyó con su propia industria. Entre sus tierras se contaban la dehesa llamada El Pamplinar y otros tantos cortijos en que pastaba su ganado, como Mata de Tora, el Calero, Cerro de la Higuera, etc. También su sobrino el deán don Francisco Pacheco, heredero con sus otros hermanos de varias tierras de secano y dehesa de su madre: los cortijos de las Mesas, de Curiel y Padilla, Haza Bermeja... 
consideración $^{21}$. Los molinos de distinta tipología y función (papeleros, de pan, de aceite...) fueron las propiedades de carácter industrial más generalizadas ${ }^{22}$ junto con los hornos ${ }^{23}$ y caleras ${ }^{24}$. Más raramente, se beneficiaron instalaciones industriales de otro tipo, sobre todo en el siglo XVI y vinculadas con la industria textil y del cuero, sectores de relativa pujanza en la Córdoba de ese momento. Manifestación de ello son las tenerías propiedad del racionero Bartolomé de Leiva, sitas frente a la Puerta de Martos $^{25}$, las curtidurías y batanes edificados por el deán don Juan de Córdoba en

21 A mitad del siglo XVI el racionero Cristóbal de Gauna basaba buena parte de sus ingresos en sus mil cuatrocientas cabezas de ganado ovino, apacentadas en el hontanar de los frailes de San Jerónimo por unos pastores asalariados, a cuya disposición tenía puestas un par de borricas y seis perros de su propiedad. En este caso no estaban dadas en arrendamiento. Gauna explotaba directamente los beneficios de la leche, la lana, las pieles y la carne producidas en el mercado de Córdoba. A su muerte se documentaron en su casa, además de varios esclavos, gran cantidad de lana fina de añino y de carnero, unos ciento treinta quesos para la venta y todo lo necesario para su elaboración (calderas, herradas, cedazos, un expremijo, etc.), dos docenas de pellejos de carnero... AHPCo, leg. 10.299-P, fols. 217r.-218v. Doscientos años más tarde seguimos encontrando intereses ganaderos entre los prebendados. Así, don Juan Ignacio de Fuentes poseía doscientas cincuenta cabezas de ganado ovino, cuarenta de porcino, treinta y tres de bovino, treinta y ocho de caballar y treinta y seis de mular; don Francisco Fernández de Córdoba ciento veinte cabezas de ganado porcino, noventa y siete de vacuno, ochenta y siete de ovino y cinco de caprino, más veinticuatro caballos y diez asnos, por citar sólo un par de ejemplos del Dieciocho. AHPCo, Catastro de Ensenada, libro 324, fols. 595r.-617r., y libro 321, fol. 78v., respectivamente.

22 Don Francisco Pacheco, por no demorarme más que en un caso, estableció en 1571 condiciones muy minuciosas para el mantenimiento y reparación de sus aceñas en el río de Monturque (AHPCo, leg. 10.319-P, fols. 1.576r.-1.578v.). La construcción de almazaras debió ir al alza a partir del XVI, al pairo del incremento del cultivo del olivar (Cf. CARANDE, R.: op. cit., p. 54). Propietario de una de estas prensas, conocida en Bujalance como Molino del Monte, era el chantre Gómez de Cárdenas, quien hacía moler en ella no sólo la producción de aceituna de sus propios olivos, sino también la de los olivares que arrendaba a terceros para luego él vender aceite (AHPCo, leg. 8.591-P, fols. 237r.-244v.), o también don Juan Ignacio de Fuentes, de cuya almazara en el pago de Linares, a una legua de la ciudad, sabemos que disponía de bodega con capacidad de 950 arrobas de aceite. En el Catastro de Ensenada se le estimó una utilidad anual de trescientos reales. AHPCo, Catastro de Ensenada, libro 324, fols. 595r.-617r.

23 Al maestrescuela don José de Navas su horno de pan en la calle de la Cruz Verde le reportaba a mediados del siglo XVIII seiscientos reales anuales brutos, idéntica renta que la que otro en la calle de Jesús Nazareno daba al canónigo Fuentes arriba mencionado. AHPCo, Catastro de Ensenada, libro 323, fols. 430r.- 438v., y libro 324, fols. 595r.-617r.

24 El 1 de enero de 1645, vistas las posibilidades de un altozano sito en una heredad de su propiedad en el término de Posadas, el racionero don Antonio de Castillejo se concertó con Juan González y Pedro Alonso para la construcción de un par de caleras con sus hornos de setenta cahíces de cabida cada una. Igualmente los contrató como caleros, pagándoles por cada cahíz de cal cocida entregado ocho reales, diez arrobas de vino y arroba y media de aceite. La heredad se componía de bosque y lagar de aceite con su almazara y el racionero se comprometía a dejarles talar toda la madera que fuera necesaria como combustible, exceptuados chaparros, alcornoques y acebuches, y a venderles el orujo de aceituna que necesitaran (¿para la fabricación de jabón, tal vez?) a seis reales y medio el cahíz. AHPCo, leg. 11.765-P, fols. 2r.-v. También el arcediano don Francisco de Simancas el viejo disponía, en una heredad de huerta, viñedos y lagar, de una calera semejante. A su muerte sus albaceas inventariaron en ella 50 cahíces de cal por vender. ARChGr, Pleitos, caja 5.380, pieza 1.

25 AHPCo, leg. 12.835-P, fols. 1.103r.-1.106r. 
Rute $^{26}$, o las estancias para majar, cocer y tender lino edificadas junto a las aceñas de don Tello a orillas del Guadalquivir ${ }^{27}$.

A partir usualmente de un cierto número de bienes heredados (no perdamos de vista la posición socioeconómica del entorno familiar del que proceden), la acumulación de patrimonio inmobiliario en sus manos respondió a una pauta de engrandecimiento con miras a la formación de lotes lo más redondos y compactos posible, a partir de la agregación de piezas de tierra próximas en el ámbito rural y de varias casas en el urbano, que revertirían de nuevo al seno de la parentela en forma ya engrosada y por lo general vinculada.

Por otro lado, la pertenencia al cabildo brindaba grandes oportunidades de cara a la tenencia de posesiones de la mesa en forma de arriendos vitalicios que, en la práctica, eran explotados casi como si de auténticos bienes en propiedad se tratara. Las condiciones fueron siempre bastante favorables (con la posibilidad de sucesión por herederos durante una o más vidas entre ellas) y el control por parte del cabildo flexible en beneficio de sus integrantes. Difícilmente resulta de otro modo cuando en las mismas manos recaen el interés individual y el colectivo. El sistema de puja con que se adjudicaban las fincas propició no pocas gangas, aunque en verdad los precios no estuvieron en apariencia muy por debajo de los del mercado inmobiliario en ese momento. De cualquier manera, los arrendadores de fincas eran los primeros interesados en mantenerlas en las mejores condiciones posibles de explotación.

Los frutos generados no eran sólo monetarios o siquiera cuantificables. De hecho, las propiedades tomadas de la mesa eran subarrendadas a menudo por cantidades que paradójicamente apenas si dejaban un margen de ganancia en metálico, y aun tan bajas que el saldo resultaba en apariencia negativo. Es obvio que estos negocios no se emprendían para perder dinero, por lo que la explicación debe residir en la obtención de beneficios de otra especie.

En primer lugar, hay que contar con la carga de prestigio inherente a la posesión de bienes raíces, tan ligados a la concepción del vivir noblemente. En segundo lugar, con los aprovechamientos paralelos. La explotación de huertas y cortijos se conjuga-

26 Tenían un valor estimado, seguramente a la baja por motivaciones que no me detendré aquí a glosar, de más de cinco mil quinientos reales, entre obra y caudal, a mediados del Quinientos. AHPCo, leg. 16.791-P, fol. $312 \mathrm{v}$.

27 En el archivo de la nobleza de Toledo se conserva una de las copias de la escritura de arrendamiento otorgada el 23 de julio de 1529 por el racionero Gonzalo de Cañete, en su nombre y en el de su hermano el jurado Francisco de Cañete como copropietarios, en favor de Marcos Ruiz y Miguel Sánchez Godino, compañeros. Este tipo de instalaciones sólo funcionaban en verano, inmediatamente después de la recolección de la materia prima, de ahí que en éste como en otros contratos que he podido ver el alquiler se limite a los meses de julio, agosto y septiembre y las cuantías no sean muy elevadas ( 8 reales en este caso). SN, Luque, caja 124, doc. 45. 
ba con el placer del esparcimiento, del que fueron escenario predilecto y para lo que disponían de casas de recreo. Asimismo era usual reservarse una pequeña parte de la producción agrícola para consumo propio, bien como derecho a compra a un precio especialmente convenido de antemano, bien como parte del pago por la tierra. En el cumplimiento de estas cargas contractuales en especie, en los distintos tiempos del año tenía lugar un desfile de hortelanos, pastores, apicultores y labriegos por las casas del eclesiástico, donde debían hacer entrega de los frutos acordados bajo términos de dádivas o pechos. Herencia de tiempos anteriores, los pagos en especie seguían estando fuertemente asociados con el reconocimiento de los derechos sobre la tierra. El significado social de todo ello como un plus a la carga de prestigio es muy digno de ser valorado en su justa medida.

También en el ámbito urbano se sacaba provecho de estas fincas más allá del estricto alquiler de los espacios como locales y viviendas. Por ejemplo, sobre algunas dependencias o elementos auxiliares (cocheras, establos, corrales, cillas, pozos...) podía mantenerse un derecho de disfrute, pero el más claro exponente de lo dicho fueron ventanas y balcones. El discurso social del Antiguo Régimen se materializaba periódicamente en la fiesta pública: procesiones, autos de fe, corridas de toros, juegos de cañas... ${ }^{28}$ En este teatro del mundo cobraba enorme valor disponer de un palco privilegiado desde el que disfrutar del espectáculo, viendo y dejándose ver. Las cláusulas de reserva de estas partes del edificio son muy frecuentes cuando su localización es próxima a ejes viarios clave de la ciudad. El alto precio que podían llegar a ofrecerse por tales piezas durante algunas celebraciones del año hacía que muchos estimaran rentable prescindir de su uso particular para alquilarlas ${ }^{29}$.

Volviendo a los bienes tomados de la mesa capitular, no olvidemos tampoco que en estos arrendamientos por una o varias vidas, en los cuales solían sucederse como en las prebendas tíos y sobrinos, el beneficio tendió a incrementarse en tanto que el precio de remate original no se renegociaba: con el paso de los años el valor nominal se mantenía, mientras mermaba el valor efectivo del mismo. Frente a ello, la tendencia tanto en los alquileres de posesiones propias como en subarriendos de casas de la catedral fue la de reducir la duración de los contratos a uno o dos años.

28 Véase a este respecto para el caso andaluz MOLINA RECIO, R. y PEÑA DÍAZ, M. (coords.): Poder y cultura festiva en la Andalucía moderna, Córdoba, Universidad de Córdoba, 2006.

29 En la década de los cincuenta del XVIII, la utilidad de cuatro vistas de balcones y diecinueve nichos a la Corredera, propiedad del racionero don Francisco Delgado y Villarán, se calculaba en 14 reales anuales (AHPCo, Catastro de Ensenada, libro 325, fols. 275r.-277r.). Similares ingresos debían reportar los tres balcones vecinos a estos de una casa propiedad del tesorero don Juan de Navas y Recio, legadas en su testamento de 1720 al cabildo para dotar un aniversario perpetuo con el alquiler de los mismos durante las fiestas (AHPCo, leg. 8.591-P, fols. 229r.-236r.). Cien o ciento cincuenta años antes el valor hubo de ser algo más elevado, cuando aún autos de fe de importancia o corridas como la celebrada con motivo de la visita de Felipe IV abarrotaban con esplendor barroco la plaza mayor cordobesa. 
Para ilustrar lo dicho, tomemos de entre las decenas de casos símiles el de don Luis de Góngora y Argote, posiblemente el más famoso de los miembros del cabildo cordobés. Centrémonos en una heredad, la Huerta de don Marcos, y una casa en la calle de la Feria, una de las más importantes vías, si no la principal, de la Córdoba de entonces, escenario de mercados, procesiones, arquitecturas efímeras, fiestas, juegos y lidias. Tanto la finca campestre como la urbana serían arrendadas con vistas a su explotación.

La casa de la calle de la Feria fue rematada en don Luis en 1587, formalizándose el contrato con la mesa capitular el 4 de diciembre de ese año por 7.500 maravedís y siete pares y medio de gallinas de renta anual por tiempo de dos vidas ${ }^{30}$. No estamos ante un alquiler por necesidades de alojamiento. El poeta había heredado en 1586 las casas principales de su tío el racionero Francisco de Góngora $^{31}$, y sólo veintiséis años después trasladaría su residencia en Córdoba a la collación de Omnium Sanctorum ${ }^{32}$. Como en esta ocasión, el prebendado en general prefiere vivir en algún barrio de la Villa o ciudad alta, cerca de la catedral, a ser posible, aunque la mayor parte de su actividad económica en este campo se concentra en la ciudad baja o Ajerquía, área más comercial. La casa de la calle de la Feria se situaba en esta última zona. Por los contratos de subarrendamiento que conocemos, nunca se pidió por la casa un alquiler que llegara a rentabilizar lo pagado a la mesa, éste montaba unos 265 reales y medio, incluidas ya las gallinas, a principios del XVII ${ }^{33}$, mientras que el precio usual del alquiler fue de 220 reales. La duración de los contratos, por otra parte, baja de al menos dos años a uno solo. Lo que sí fue siempre denominador común es la reserva de las tres grandes ventanas a la calle, lo cual da buena cuenta del valor que en el aprecio de don Luis debieron tener para hacer bueno el negocio ${ }^{34}$.

30 Mientras el alquiler en metálico permanecía inalterable, el precio de las gallinas dependía del mercado, lo que hacía variar el precio. Lamentablemente no disponemos de listas de precios para la Córdoba moderna, pero por los ajustes de cuentas entre administradores y prebendados vistos puedo indicar que el par de gallinas vivas en el XVI, unos años antes de este contrato, podía costar en Córdoba 4 reales, subiría a 6 reales (más raramente 5,5 reales) para principios del XVII y a 10 reales a mitad de esa centuria.

31 Estas casas, sitas en la collación de Santa María, habían quedado vinculadas por su testamento de 1582 como parte de un mayorazgo en que habría de suceder en primer lugar la línea de don Juan de Góngora, pero antes gozaría del usufructo su hermano don Luis, «por ser clérigo e no aberse de cassar». SLIWA, K.: Cartas, documentos y escrituras de Luis de Góngora y Argote (1561-1627) y de sus parientes, Córdoba, Universidad de Córdoba, 2004, vol. I, pp. 163-167 (la cita en p. 165).

32 Se trataba de unas casas principales tomadas en arrendamiento de la mesa capitular por dos vidas. El contrato, por 37.500 maravedís y 37 pares de gallinas al año, se realizó mediante poder otorgado a su sobrino don Luis de Saavedra el 16 de febrero de 1612 (Ibidem, pp. 532-533). Debe de tratarse de la vivienda en que murió en 1627, en la plaza de la Trinidad.

33 Estimado el precio de las gallinas vivas por el de los ajustes de cuentas del mismo don Luis en 6 reales la pareja.

34 En el contrato por dos años hecho al guadamecilero Miguel Ruiz el Lindo en 1601, se dice expresamente «con condizión que cada e quando ubiere fiestas o rregozixos en la dicha calle de la Feria se obligó de dar a el dicho don Luis de Góngora o a quien él quisiere tres bentanas que tiene el primer agimez 
La aún conocida como Huerta de don Marcos era una plantación de frutales y olivos a una media legua de distancia al norte de la ciudad, ya en las faldas de la Sierra, regada por el arroyo Pedroches. Disponía asimismo de una casa de campo con su torre, alberca y fuente, de la que Góngora hacía uso como lugar de esparcimiento, convalecencia y retiro estival. Había sido arrendada al cabildo en 1602 por dos vidas y precio de 18.000 maravedís y 18 pares de gallinas al año, con las condiciones típicas $^{35}$. Es interesante ver la evolución de los sucesivos contratos: la duración de los subarriendos fue disminuyendo mientras aumentaba ligeramente lo percibido por el racionero. Si llegó a existir una pequeña plusvalía en dinero o en especie, no justificó por sí misma el interés en este tipo de inversiones, que solía residir en otros aprovechamientos como los antes comentados. El 16 de octubre de 1607 la entregó para su explotación al hortelano Pedro Gómez de Portichuelo por 20.000 maravedís anuales todo o parte en frutos, durante cuatro años ${ }^{36}$. Luego parece haber sido dada en similares condiciones por los tres años siguientes a Alonso y a Juan Molina, hortelanos ${ }^{37}$. Entre 1613 y 1615 se arrendó por dos años al labrador Tomé Fernández, a cambio de una renta anual de 20.000 maravedís más tres fanegas de aceitunas verdes de mesa, cuatro capachos de brevas y otros tantos de ciruelas, mil nueces, 500 granadas dulces y 300 agridulces $^{38}$. Como ha señalado Robert Jammes,

Don Luis no ganaba nada en este negocio, pero tenía la satisfacción de poder disponer de una casa de campo a las puertas de Córdoba: la descripción que de ella da el acta de 1602 indica que se trataba de una propiedad agradable, fértil y umbrosa. Don Luis tenía también la ventaja de poder hacerse pagar en frutos, lo que le permitía disponer de aceite, leña y frutas de buena calidad ("aceitunas, ciruelas tempranas, brevas, ciruelas de fraile, ciruelas zaragozíes, duraznos, endrinas ubillas, higos verdes, higos apartados, granadas, uvas, nueces verdes") durante la mayor parte del año. (...) El disfrute de esta propiedad debía suponer una ventaja apreciable, puesto que en 1616 Luis de Saavedra, sobrino y coadjutor de Góngora, hizo que el contrato se prorrogase en su favor: obtuvo el arrendamiento vitalicio a su nombre, con la obligación de plantar otros árboles, hacer las reparaciones necesarias y reemplazar los chopos por moreras ${ }^{39}$.

de la dicha casa». El 8 de julio de 1610 la casa se alquiló por un año al bordador Luis Florián de Ocampo, siendo igualmente «condiçión que para los días o noches que ubiere fiestas, regoçijas o proçesiones en la dicha calle de la Feria, es y queda para el dicho Raçionero don Luis de Góngora y quien fuere su boluntad el ajimés bajo que tiene la dicha casa, el qual dejará libre y desocupado sin desquento de renta». Ibidem, pp. 292 y $522-523$.

35 Ibidem, pp. 296-301. Al precio común de 6 reales el par de gallinas en ese momento, suponía un total de 21.672 maravedís o algo más de 637 reales a pagar al cabido cada año.

36 Ibidem, pp. 442-445.

37 SLIWA, K.: op. cit., vol. II, pp. 568-569.

38 AHPCo, leg. 10.766-P, fols. 283r.-285v. De regular estas cargas en frutos a los precios que aparecen en la escritura de 1607, supondrían unos 102 reales que añadir al alquiler en metálico.

39 JAMMES, R.: op. cit., p. 14. 
La Huerta de don Marcos llegaría a ser para él, en efecto, la encarnación de ese topos literario tan presente en su poesía, el de la bucólica tranquilidad del campo frente a la vida cortesana ${ }^{40}$. El sobrino, no obstante más prosaico y mejor heredero de la mentalidad financiera de su tío abuelo el racionero Francisco de Góngora, sabría sacar mejor provecho a su turno ${ }^{41}$.

\section{La inversión en deuda}

Entre las estrategias económicas hay que señalar la inclinación de los prebendados al situado de capital. Nada nuevo es constatar la excepcionalidad de la inversión directa en compañías comerciales o bancarias ${ }^{42}$. La compra de juros, aunque de mucha mayor presencia, no tuvo tampoco sino un peso secundario en el conjunto de inversiones de los miembros del cabildo, al menos en comparación con la actividad crediticia a nivel particular, que alcanzó en sus filas un desarrollo sin parangón con otros sectores del clero diocesano.

El incumplimiento en los pagos y el hecho de que fueran quedando reducidos colaboró grandemente a este menor peso de los juros. Cuando una parte de los ingresos la componen rentas procedentes de estos instrumentos, se trata en la mayoría de los casos estudiados de bienes dotales de alguna de las capellanías que se poseen: el canónigo Juan Bautista de Buiza cobraba 320,8 reales al año del juro sobre las alcabalas de Bujalance de la Capilla de Santa Marta, 441 reales sobre las alcabalas de Córdoba el racionero Andrés Chirino de Morales por la capilla de los Sosa en la catedral, de 168 reales también sobre las alcabalas de Córdoba disfrutaba el racionero Anto-

40 Ibidem, p. 109.

41 Mantuvo los subarriendos por dos años, como en el efectuado en 1623. Bajó la renta en metálico a 17.000 maravedís, pero agregó el pago de quince pares de gallinas, casi como si a título de propiedad disfrutara de la huerta. Al precio que alcanzarían en lo venidero, el pago añadido de las gallinas serviría para saldar las cuentas cada año con la mesa capitular sobradamente, o incluso para sacar algunos reales de beneficio. A ello añadió además la entrega a domicilio, libre de costas e impuestos, de «seisçientas granadas dulzes y un capacho de çiruelas tempranas y otro capacho, que se entiende de arroba, de mançanas açucaríes y otro capacho de mançana ocal y otro de ciruela çaragoçí y otro de brebas y una arroba de higos pasados y dos fanegas de aceitunas mançanillas para echar en agua y quatroçientas nuezes, puesta e pagada la dicha renta en las casas de la morada del dicho don Luis de Saabedra (...) al tiempo de la cosecha de cada cosa». Se reservaba pues los productos más finos y escogidos. SLIWA, K.: op . cit., p. 866.

42 No obstante se da algún que otro caso, como el del maestrescuela don Francisco Morillo, quien en el último cuarto del XVI tenía depositados en la compañía de los hermanos Juan Jerónimo y Ascanio Composta, mercaderes y banqueros napolitanos, una cierta cantidad de dinero. Al 9\% de interés anual, el capital ascendía según el informe de cuentas del 6 de mayo de 1587 a 4.702 ducados de oro y 6 granos en moneda de Nápoles. Hemos de suponer pues que al traspasar el depósito a nombre de su sobrino y coadjutor, don Rodrigo Velarde de Morillo, éste rondaría ya los cinco mil quinientos ducados. La escritura de donación y traspaso se realizó en Córdoba, en la casa del maestrescuela, el 31 de agosto de 1589. Puede consultarse en AHPCo, leg. 10.374-P, fols. 1.493r.-1.497r. 
nio Sánchez de Almoguera por su capellanía de San Pedro, el canónigo don Francisco Fernández de Córdoba de la mitad de un juro reducido a 1.746,7 reales de renta sobre el almojarifazgo de la ciudad como capellán de la Capilla de la Resurrección, el racionero don Diego Carlos de Valenzuela, como capellán de la capellanía fundada por don Francisco Venegas en el convento de San Pedro el Real, un juro reducido a 1.640 reales al año sobre las alcabalas de Écija... ${ }^{43}$ La lista podría continuar, pero no serviría sino para hacer más patente la diferencia entre quienes ingresan un dinero procedente de juros, que ha de ser englobado como he dicho en las dotaciones de las capellanías que acumulan, y quienes tienen en ellos un campo de inversión. Estos últimos fueron verdaderamente pocos.

Hubo, es cierto, quien invirtió varios miles de reales en este concepto. En 1619 el deán don Diego Sarmiento de los Cobos poseía seis juros situados sobre diferentes rentas (tercias reales, azúcar de Granada, las Alpujarras, etc.), uno de los cuales, de 110.000 reales de principal a veinte mil el millar, sirvió de dote a las cuatro capellanías que fundó en el convento de Nuestra Señora de la Piedad de Granada ${ }^{44}$. Más de 130 años después el racionero don Pedro Fernández de Córdoba declaraba entre sus bienes temporales tres juros: uno de 536 reales anuales sobre el servicio de millones de Toledo, otro de 885 reales sobre las alcabalas de Madrid y su partido y un tercero de 1.008 reales sobre las alcabalas de Murcia. Disfrutaba además como patrono de una obra pía de un pequeño juro de 26 reales anuales sobre los servicios ordinario y extraordinario de Toledo ${ }^{45}$. Pero son solamente excepciones que confirman la regla.

Sus posibilidades de liquidez hicieron de los prebendados agentes de crédito de gran importancia, sobre todo en ciudades de pequeño y mediano tamaño, según la capacidad y manejo económico de cada individuo. El espectro de este mercado crediticio abarcaba desde el ámbito local más próximo y modesto (empeños y pequeños empréstitos a vecinos, criados, compañeros o parientes, de los que muchas veces queda escasa huella documental), hasta grados más significativos cuantitativa y cualitativamente a nivel regional. De ello son reflejo los censos consignativos otorgados contra estados señoriales o municipios, que ayudaron a financiar ya fuera la adquisición de las alcabalas de una localidad por el señor, ya la exención de una villa de su jurisdicción anterior. En ocasiones, los límites geográficos de estos circuitos de préstamo sobrepasaron los del reino de Córdoba, extendiéndose a aquellas zonas de especial vinculación socioeconómica con éste, como era la serranía malagueña, o con los propios prebendados, caso de las áreas de procedencia de los foráneos.

43 Véase en este mismo orden AHPCo, leg. 10.766-P, fols. 232v.-233r., 334r. y 527r.-v., y Catastro de Ensenada, libro 321, fol. 78v. y libro 323, fol. 469r.

44 AHPCo, leg. 10.297-P, s.f.

45 AHPCo, Catastro de Ensenada, libro 324, fols. 943v.-945v. 
Entre los distintos créditos concedidos por el tesorero don Antonio de Corral en la primera mitad del XVI, encontramos desde un censo perpetuo de 1.100 reales de principal, que apenas si renta 55 reales al año, impuesto sobre la hacienda de Per Álvarez de Montalbán, cura de Almorox ${ }^{46}$, a un par de censos redimibles de 77.000 y 38.500 reales de principal contra los bienes del marqués de Comares y propios de Lucena de una parte y los bienes de propios de Córdoba de la otra, respectivamente ${ }^{47}$. Un siglo después, el arcediano don Andrés de Rueda Rico era propietario de diez censos al quitar, de los cuales la mitad, por un monto de 231.300 reales, habían sido otorgados al marqués de Priego para la adquisición de las alcabalas de Aguilar y de Puente de don Gonzalo. El resto, salvo uno dado a don Rodrigo Serrano de Cárdenas, estaba cargado sobre bienes municipales: dos contra los del concejo de Cártama que sumaban 179.453 reales y medio, 44.000 al de Andújar ${ }^{48}$, 2.200 al de Antequera... ${ }^{49}$ A un interés estipulado del 5\%, más el premio de la plata, la renta anual cobrada por todos ellos ascendía a la bonita suma de 24.005 reales y 26 maravedís. Otros tantos censos impuestos contra bienes de propios y arbitrios podrían enumerarse. Tan sólo durante la primera mitad del XVII la ciudad de Antequera obtuvo dos del racionero Baltasar Nájera de la Rosa, la de Lucena uno de 22.000 reales de principal del racionero Juan Jiménez de Bonilla, otro de 30.000 reales Montoro del medio racionero Felipe de Baena Palenzuela para su exención... ${ }^{50}$

También el cereal fue objeto habitual de préstamo. A menudo se trataba de simples asientos en los libros de cuentas pero, de ser necesarias ciertas garantías, los préstamos de grano se realizaban por medio de libranzas o, más frecuentemente, de escrituras públicas de obligación en que quedaban establecidas las condiciones del pago $^{51}$.

Esta actividad crediticia se desarrolló en diferentes modalidades de acuerdo a la finalidad, al capital montante y a la mayor o menor necesidad de garantías prendarias. Encontramos pues un uso generalizado de los distintos instrumentos de crédito

46 Se trata de la localidad toledana de origen de la familia Corral.

47 AHPCo, leg. 10.294-P, s.f.

48 Originalmente la suma prestada al concejo de Andújar fue de 110.000 reales, pero don Andrés donó de ellos 66.000 reales como principal de un censo al Colegio Mayor de Santa Cruz de la Universidad de Granada, donde fuera colegial. AHPCo, leg. 11.758-P, fol. 563v.

49 Ibidem, fols. 561r.-563v.

50 Para las referencias citadas, véase, según el mismo orden, AHPCo, leg. 11.767-P, fols. 108 r.-v. y 383r.-v., y AHPCo, Protocolos Notariales de Montoro, leg. 6.900, fol. 293r.

51 En la obligación otorgada el 6 de junio de 1643 por el lagarero Francisco de Castro, éste se comprometía a devolver las 36 fanegas de trigo prestadas por el racionero don Juan de Góngora y Armenta el día de San Miguel de septiembre de ese mismo año, haciendo la entrega en la casa del clérigo, especificándose como medida la fanega de Ávila oficialmente adoptada desde Felipe II. AHPCo, leg. 11.762-P, fols. $862 \mathrm{r}$.-v. 
disponibles para la época: censos consignativos, letras de cambio, obligaciones, libranzas, préstamos simples o empeños.

Más dificultades se presentan ante la pretensión de calcular las ganancias reales que de ello se derivaban. Raramente aparece la expresión del interés por parte alguna, salvo en escrituras de censo, y aun tras éstas pueden esconderse cuantías superiores a las manifestadas. Suele suceder en esta y otras situaciones que sólo el conflicto haga partícipe al investigador de lo que a todas luces fueron realidades no por menos manifiestas del todo cotidianas ${ }^{52}$.

Los censos al quitar o redimibles funcionaron como herramienta de empréstito ${ }^{53}$ cuyos réditos solían pagarse cada cuatro meses, los llamados "tercios acostumbrados" $"$. Desde 1534 sucesivas medidas legislativas procuraron para Castilla la reducción del interés por el capital tomado, o al menos que éste quedara fijado y no a criterio del censualista. A partir de esa fecha, el interés legal vigente fue de catorce mil el millar, un 7,14\%, y no sería rebajado al 5\% (veinte mil el millar) hasta la pragmática de 1608, que tuvo efectos retroactivos. El incumplimiento, empero, debió de estar a la orden del día a juzgar por las reiteraciones de la medida en 1548, 1563 y $1573^{55}$. No faltan manifestaciones de ello como la del racionero Valerio Ruiz de Córdoba, que en mayo de 1547 prestaba a censo redimible al señor del Carpio, don Diego López de Haro, y a doña María de Velasco, su mujer, 300.000 maravedís a razón de doce mil el millar, esto es al 8,3\% de interés anual ${ }^{56}$. Finalmente, en 1705 quedaría situado en un $3 \%{ }^{57}$. ¿Provocó esta rebaja una retracción en la inversión en censos por parte de los

52 Muy jugosas en este sentido son las declaraciones en el pleito que enfrentó al cabildo con los herederos de la fortuna del difunto arcediano don Francisco de Simancas el viejo hacia 1520. En el cruce de acusaciones de usuras, amancebamientos, simonías o falta de limpieza de sangre, uno de los testigos explica cómo «el dicho don Françisco de Simancas le prestó al dicho Pero Díaz treinta mil maravedís para fazer la botica de su ofiçio, e que por ellos le daba al dicho arçediano tres mil maravedís cada año e otros tres de çenso sobre la dicha tienda». En otras palabras, aparte del 10\% de interés recogido en la escritura de préstamo a censo, el arcediano exigía otro tanto, esto es, el interés real era del $20 \%$. Sorprende constatar que tras estas y similares explicaciones de los testigos, el infamado públicamente de logrero usurario fuera el boticario. ARChGr, Pleitos, leg. 5.380, pieza 1, s.f.

53 El funcionamiento de los censos perpetuos fue diferente, muy relacionado con la transmisión de la propiedad a modo de censos enfitéuticos o con la creación de muy pequeñas rentas (para el mantenimiento de aniversarios o memorias de misas, por ejemplo), y su presencia muchísimo más escasa.

54 Las fechas de liquidación de cada tercio correspondían aproximadamente con las festividades de San Juan Bautista en junio, Todos los Santos en noviembre y Carnestolendas. Otras veces se establecían sólo dos plazos.

55 BALLESTER MARTÍNEZ, A.: "Los censos: concepto y naturaleza”, Espacio, Tiempo y Forma, Serie IV, Historia Moderna, 18-19, 2005-2006, pp. 38-39.

56 Se trataba del capital aportado por el racionero a un principal por cuantía de 408.000 maravedís (12.000 reales) compartido con el escribano público Gonzalo de Toledo el joven. AHPCo, leg. 16.793P, fols. 403r.-409v.

57 BALLESTER MARTÍNEZ, A.: op. cit., p. 39. 
prebendados? Así lo cree para el caso canario Pedro C. Quintana Andrés ${ }^{58}$. Para el territorio francés, la situación parece haber sido diferente, conservando en el XVIII su equivalente galo, la rente constituée, buena parte de su atractivo para el clero, como demuestran los estudios de Loupès, Charles o Wenzel para las regiones de Guyena y Bretaña o la diócesis de Dijon ${ }^{59}$. Por mi parte, no he logrado detectar señales determinantes de esta retracción ni siquiera a mediados de $\operatorname{siglo}^{60}$. Puede que un más profundo estudio económico de la cuestión revele en efecto una clara tendencia a la baja, como parece intuirse. De ser así, las medidas de 1705 no serían desde luego la única ni la más importante explicación. Como parte de las estrategias económicas, la actividad crediticia no tuvo en la obtención de grandes beneficios dinerarios su único objetivo.

En cualquier caso, el activo inmovilizado a largo plazo mediante la venta de censos consignativos compuso una parte no desdeñable del patrimonio de muchos prebendados, tanto por el valor montante como por la tranquilidad que ofrecía su carácter de capital a renta fija sin una fecha estipulada de liquidación. Esto hizo de ellos uno de los títulos de propiedad más recurrentemente vinculados de cara a la dotación de obras pías y mayorazgos, además del instrumento más utilizado a la hora de prestar cantidades relativamente importantes de dinero.

Los préstamos podían asimismo formalizarse mediante cédulas o letras de cambio, escritas y firmadas por la persona a quien se prestaba el dinero, que se compro-

58 «La modificación del interés en 1705 supuso una retracción en la estipulación de censos consignativos al no resultar ya rentables, salvo si eran de amplia cuantía, desapareciendo los pequeños y medianos préstamos... En el siglo XIX el préstamo ha quedado totalmente relegado en los testamentos de los prebendados». QUINTANA ANDRÉS, P. C.: A Dios Rogando y con el mazo dando: fe, poder y jerarquía en la Iglesia canaria (el Cabildo Catedral de Canarias entre 1483-1820), Las Palmas de Gran Canaria, Cabildo de Gran Canaria, 2003, p. 309.

59 LOUPÈS, Ph.: op. cit., p. 295. CHARLES, O.: Chanoines de Bretagne: carrières et cultures d'une élite clérical au siècle des Lumières, Rennes, Presses Universitaires de Rennes, 2004, pp. 188-189. WENZEL, E.: Curés des Lumières: Dijon et son diocèse, Dijon, Editions Universitaires de Dijon, 2006, p. 109. No se trata en mi opinión de una diferencia en cuanto a las mentalidades de canónigos franceses y españoles, muy por el contrario los paralelismos son enormes. Donde sí existió diferencia fue en la legislación reguladora de estos instrumentos de préstamo, que en Francia aseguró un interés del 5\%. $C f$. LOUPÈS, Ph.: op. cit.

60 Se siguió concediendo censos de distinta cuantía. En los años cincuenta, don Francisco José de Sabariego era propietario de una docena de ellos, entre los que destacan los 78.560 reales y medio prestados en un par de censos redimibles a la marquesa de Almodóvar. Sus ingresos anuales en cuestión de réditos ascendían a 4.750 reales y 9 maravedís (AHPCo, Catastro de Ensenada, libro 323, fols. 440v.$449 v$.). Con esta tasa los impuso también el racionero don Cristóbal de Figueroa y Alfaro: el 28 de marzo de 1764 contra don Manuel Díez de Castañeda, teniente del regimiento de caballería de Granada, por 51.500 reales, el 2 de diciembre de 1766 contra don Félix Rodrigo de Angulo, vecino de Alcaudete, por 16.500 reales, o el 25 de enero de 1768 por 66.000 reales sobre varios cortijos y lagares de los trinitarios calzados de Córdoba. Los tres suman unos intereses anuales de más de cuatro mil reales (AHPCo, leg. 13.468-P, fols. 400r.-420v.). 
metía a devolver la cantidad acordada en un futuro. La cédula quedaba en poder del prestamista, quien recuperaba el capital y los intereses en el tiempo determinado por ésta (podía ser una fecha concreta, un plazo de tiempo desde que se hubiera hecho efectivo el préstamo, o quedar sin determinar para ser cobrada en el momento que el acreedor estimase oportuno).

Las obligaciones de pago fueron también en la práctica títulos de crédito por los que el prestatario se comprometía a devolver la cantidad prestada, aunque con otras características. La obligación se otorgaba en favor del prestamista ante escribano, con lo que era protocolizada, cobrando carácter público. Jamás se expresa en la escritura que exista un interés sobre el capital, sino tan sólo el supuesto deseo del librador de hacer "buena obra y merced" al beneficiario ${ }^{61}$. Por contra, a diferencia de las cédulas, en las obligaciones suele especificarse una serie de condiciones tales como plazos de pago concretos, unidad monetaria requerida (reales de plata, moneda de vellón...), avales, fiadores, etc. Por lo general, aunque no siempre, la obligación suponía para el deudor un pasivo exigible a corto plazo, acordándose una fecha concreta dentro del año corriente ${ }^{62}$.

Entre las escrituras de deuda que el canónigo Alonso de Buitrago dejó a su muerte el verano de 1614, sus albaceas hallaron quince obligaciones. El valor medio de lo prestado rondaba los 115-130 reales, cantidades muy inferiores a las que componían el principal de sus censos ${ }^{63}$. Casi todas ellas habían sido otorgadas en Torremilano o en Santaella, ante un mismo escribano público en cada una de estas localidades y parece probable que hacia los mismos días, dado que la fecha de devolución es la misma (25 de julio para los vecinos de Santaella, 15 de agosto para los de

61 Los términos en que se expresan estas escrituras son siempre por el estilo de la que sigue, relativa a un préstamo de cuatrocientos reales hecho el 20 de julio de 1645 por el racionero don García Álvarez de Benavides al sacerdote Andrés Gómez del Castillo: «...maravedís que le debe por otra tanta cantidad, que por él hacer buena obra le presta en moneda de vellón, y los recibe de su merced realmente y con efecto en presencia del escribano público de Córdoba y testigos deyuso escritos que fueron presentes y le vieron hacer el dicho entrego, del cual y de su recibo, yo el dicho escribano doy fe que se hizo en mi presencia y de los dichos testigos, por cuya razón pagará los dichos cuatrocientos reales en esta ciudad de Córdoba luego, cada y cuando el dicho señor doctor don García Álvarez de Benavides los quisiere, y con sólo la presentación de esta escritura» (AHPCo, leg. 11.766-P, fols. 912r.-v.).

62 En la escritura otorgada en enero de 1614, don Antonio Venegas se obliga a pagar al racionero Fernando Sarmiento 9.619 maravedís, «los cuales conozco debelle por otros tantos que me da prestados, de que me otorgo por entregado». Se le concedieron seis meses de plazo para devolverlo, hasta el 30 de junio de ese año. AHPCo, leg. 10.766-P, fol. 135v.

63 El doctor Buitrago tenía en su favor un censo perpetuo de 4.400 reales de principal y censos al quitar por 13.200, 1.100, ó 5.500 reales... Quizá la única excepción son los mil reales que le debía su sobrino Pablo de Ortigosa por «escritura pública». De tratarse de una obligación, como parece, nunca exigió la liquidación de la deuda, que terminó por ser perdonada como parte de su legado testamentario al sobrino. $\mathrm{Ni}$ siquiera aparece ya entre las escrituras de deuda del inventario post mortem unos días después. AHPCo, leg. 10.766-P, fols. 1.237r.-1.240r. y 1.264r.-1.266r. 
Torremilano ${ }^{64}$, lo cual nos habla de zonas determinadas en la actividad de préstamo, desarrollada de forma periódica en el caso de obligaciones y otros pequeños créditos a corto plazo y que hemos de situar, como la actividad económica en su conjunto, en el contexto de un denso entramado de relaciones sociales. No se trata de un fenómeno aislado, desde luego, aunque ahondaremos en él al final.

Otra herramienta muy empleada fue la libranza, una orden de pago dada por el librador a un librado en favor del beneficiario. Este sistema incluye a una tercera persona, que actúa como mero elemento de transmisión, empleando en la libranza un dinero que puede cobrar inmediatamente al librador ya que suele ser alguien con algún tipo de control sobre los ingresos de los prebendados, como administradores particulares o mayordomos de la mesa capitular. Es un método de préstamo habitual entre prebendados, que contaban con la figura de estos oficiales de la mesa como librados, así como para el préstamo a favor de familiares y criados. A menudo estos préstamos eran requeridos y otorgados por carta entre puntos geográficos distantes, empleando como digo a un tercero, en este caso algún viajero o comerciante. No era raro que la devolución del dinero tuviera lugar también por medio de una libranza.

A través de las cuentas del mayordomo de don Andrés de Rueda puede observarse el constante envío de libranzas de este arcediano desde Madrid, donde debía permanecer por temporadas atendiendo a sus ocupaciones como miembro del Consejo de la Suprema. Una de ellas nos lo muestra en el centro de un circuito monetario más complejo, de carácter transnacional. En 1639, ante la necesidad de desembolsar un dinero en Lucena y la dificultad de hacerlo mediante una libranza directa desde el norte de Italia, el capitán Rodrigo Fernández de Córdoba, teniente del castillo de Milán, decide recurrir a un intermediario idóneo como el arcediano, lucentino a caballo entre Córdoba y Madrid con residencia en las tres ciudades. Rodrigo Fernández de Córdoba habría tenido ocasión de conocerlo pocos años antes, cuando desempeñara el cargo de visitador del ducado de Milán encomendado por el consejo de Italia. De modo que tras cobrar los 400 reales de plata de manos del mercader madrileño Jerónimo Leva, a quien se había enviado letra de cambio desde Milán, don Andrés mandó a Córdoba el 1 de noviembre de 1639 orden de pago por valor equivalente en vellón

64 Se trataba de escrituras otorgadas ante Pedro de Luque, escribano público de Luque (obligación del licenciado Pedro Muñoz de Aguilar, vecino de Belmonte, por 420 reales), Luis Pérez Márquez, escribano público de Santaella (obligaciones del regidor Juan Ruiz Serrano por 154 reales, de Alonso Chaparro por 90 reales y de don Andrés de Isla y Zayas por 63 reales, todos vecinos de Santaella), y Pedro Pilarro, escribano público de Torremilano (obligaciones de Pedro Bueno por 45 reales, del escribano público de Torremilano Diego Sánchez por 180 reales, de Diego de Peralta por 90 reales, de Bartolomé Ruiz de la Moyana por 90 reales, de Diego del Pozo por otros 90 reales, de Pedro Martín Pedrajas por 280 reales, de la viuda Marina Fernández por 90 reales, de Juan Ruiz del Hoyo por 120 reales, y sendas escrituras de obligación de Martín García Herruzo y Benito González Pastor por un monto conjunto de 135 reales). AHPCo, leg. 10.766-P, fols. 1.264r.-1.266r. y 1.268r.-1.272r. 
a lo cobrado por él en moneda de plata en Madrid. Días después su mayordomo recibía la libranza en el correo y hacía efectivo sobre los caudales que manejaba un pago de 556 reales de vellón a favor de don Fernando Niño Siruendo, vecino de Lucena. El mecanismo parece haberse repetido con anterioridad, como en abril de ese mismo año, en que el arcediano había enviado a Córdoba libranza por 15.000 reales en favor de Francisco Hurtado de Valderrama, por otros tantos cobrados por él en Madrid del mismo Jerónimo Leva ${ }^{65}$.

De los préstamos simples por acuerdo entre particulares apenas si conocemos por lo general más que el capital y el nombre del beneficiario, como quedaba asentado en el libro de cuentas. Las cantidades son muy dispares, pero abundan entre los prestatarios los parientes, clientes, amigos y conocidos de confianza. Quizá por eso una forma corriente de devolverlos, además de uno de los pocos reflejos en la documentación pública de los mismos, fuera la concesión de poderes notariales. En ellos se reconocía la deuda y se cedía el cobro de alguna renta hasta que quedara saldada, tal como hizo don Pedro de Vargas el 6 de abril de 1611 y el 11 de febrero de 1614. La primera vez dio poder al canónigo don Luis Ponce de León para cobrarse su deuda de mil reales sobre el arrendamiento que había de pagar Antonio del Río, en septiembre y diciembre de ese año, por el Cortijo de la Torrecilla. La segunda, para hacerlo por cuantía de 1.100 reales sobre el alquiler de unas casas en la calleja del Capitán Juan de Carranza, pagadero el día de San Juan de junio de $1614^{66}$. Como podrá imaginarse, no se trataba de desconocidos: el acreedor era concuñado de doña Juana de Espinosa, mujer del dicho don Pedro.

Finalmente nos encontramos con empeños de diverso valor, desde unos pocos reales a varios cientos por joyas, piezas de tela, ropa... La prendería parece haber sido, desde luego, práctica común a los miembros del clero secular que disfrutaron de una cierta disponibilidad de efectivo ${ }^{67}$, en la que estaba, vuelvo a insistir, una de

65 AHPCo, leg. 11.758-P, fol. 568v.

66 AHPCo, leg. 10.766-P, fols. 230r.-232v.

67 Sirva de muestra un botón. El capellán del monasterio de Santa María de las Dueñas Pedro de Torquemada conservaba a su muerte en 1571 varios bienes empeñados por todo tipo de personas: un cáliz del monasterio de la Santísima Trinidad por 220 reales, dos tazas de plata del fiscal Mateo Gutiérrez por otros 220 reales, un paño de corte de las hermanas de un tal Andrés Fernández por 55 reales, otro paño de corte de García de Roelas por 40 reales, un pedazo de lienzo de estopa de una morisca por 8 reales, dos fundas de almohada labradas de grana, propiedad de la mujer de Juan de Torquemada, a cambio de 8 reales, un paño de manos labrado de grana de doña Francisca de Roelas por una cantidad sin especificar, una faldilla de terciopelo verde de una tal Espinosa, vecina del capellán, por 11 reales... AHPCo, leg. 10.317-P, fols. 47r.-49r. Cabe señalar, y algo de esto puede observarse en el ejemplo citado, la constante aparición de mujeres entre aquellos que recurrieron al empeño para la obtención de pequeñas cantidades de dinero. Medios mayores requerían la consignación de propiedades o el otorgamiento de una obligación de pago, en cualquier caso acciones que jurídicamente requerían el aval de bienes, la existencia de fiadores y, sobre todo, el permiso del padre o del marido, condiciones todas ellas innecesarias en este tipo de transacciones privadas de pequeña cuantía. 
las claves del papel de los prebendados en la economía local. Es corriente constatar en los inventarios de bienes la existencia de arcas, bufetes o escritorios donde se guardan ciertas cantidades de dinero en diferentes monedas ${ }^{68}$ junto a conjuntos más o menos variopintos de prendas, envoltorios y hatillos, en los que a menudo se prenden notas con indicación de su dueño, precio del empeño y aun la fecha del mismo ${ }^{69}$.

Activo prestamista en la Córdoba de Felipe II fue el canónigo Juan Pérez Mohedano de Valenzuela. Para nuestra fortuna, el detallismo de las fuentes documentales con que contamos permite recomponer la instantánea de todo lo que se le adeudaba a su muerte en $1590^{70}$. Su caso entre muchos otros no es significativo tanto por el volumen de capital entregado (algo por encima de los trece mil ducados en más de un centenar de préstamos) cuanto, particularmente, por la variada tipología de las deudas a su favor, que atravesaban todo el territorio y el tejido social cordobés.

Aunque concentrados en Córdoba y en la zona de origen de los Mohedano en torno a Pedroche y Pozoblanco, los deudores de este canónigo se repartían también por diversos puntos de la geografía castellana: Granada, Sevilla, Zamora, Santiago de Compostela... Sólo a través de la recreación de las redes sociales en que vivía envuelto el individuo es posible desentrañar, y no siempre con éxito, la naturaleza de estos intercambios de capital en que la mediación de terceros fue constante. La elección de prestatarios, otorgantes, fiadores, avalistas, librados... no es casi nunca casual y sirve

68 El maestrescuela don Juan Ruiz de Córdoba tenía en un cofre grande, junto a diversos objetos de plata, 2.310 reales en esta moneda y en ducados de oro. El canónigo Alonso de Buitrago guardaba en los cajones de un escritorio 1.269 reales en moneda de plata, 17 y un cuartillo en vellón, y un depósito de 342 escudos de oro en doblones de a cuatro y de a dos realizado por el canónigo Lupercio González de Móriz. El racionero Rodrigo Muñoz Bermúdez 1.500 reales en moneda de vellón y otros mil en reales de plata dobles y sencillos; disponía asimismo de un bufete contador de ébano donde podía conservar el dinero. Véase respectivamente AHPCo, leg. 13.241-P, fol. 288r.; leg. 10.766-P, fols. 1.264r.-1.266r.; leg. 12.788-P, cuadernillo suelto, s.f.

69 Entre los bienes del difunto Gonzalo de Cañete sus albaceas encontraron una sarga de cama labrada y, asido en ella, un papelito en que decía: «Esta prenda es de su mujer de Membrilla. Está empeñada en dos ducados. Llevólos Juan de la Nava. Viernes veinte e cuatro de setiembre de mil e quinientos e veinte e nueve años» (SN, Luque, caja 537, doc. 7).

Para recapitular todo lo dicho sobre la prendería valga el inventario de un clérigo cordobés canónigo en Valladolid, Gonzalo Estaquero. En 1557, guardaba en un cofre de cuero bajo llave varios miles de reales en doblones, coronas, doblas, reales de a cuatro, de a dos y sencillos en diferentes bolsas, además de objetos empeñados (dos anillos de oro con piedras falsas, un anillo de sello con una M esmaltada, etc.), todos cuidadosamente envueltos en papel con notas referentes a su respectivo dueño y la cantidad entregada a cambio, tipo «Pedro de Santisteban, está por catorce ducados», escrito en el envoltorio de un paquete que contenía un libro de horas guarnecido de oro y una cadenita con dos joyeles, o en un atadillo: «hay aquí sesenta coronas, son de Francisco Lomelín, están empeñadas por seiscientos reales», en que puede verse bien el interés llevado, habida cuenta de que el verdadero valor del empeño rondaría los 617 reales y medio. ARChV, Pleitos civiles, Fernando Alonso (F), caja 1.059, doc. 2, s.f.

70 AHPCo, leg. 12.406-P, fols. 373r.-388v., 507v.-509r. y 768r.-773v. Para excusar la prolijidad de notas a pie de página, me remito a esta cita para todas las siguientes referencias a préstamos de Juan Pérez Mohedano de Valenzuela. 
como indicador de vínculos de parentesco, amistad y patronazgo, o varios de ellos a la vez, previos o en formación. Difíciles de rastrear, estos lazos terminan tarde o temprano por salir a relucir con el cruce de las fuentes. La adscripción social es igualmente multiforme, como puede verse en otros casos. En la nómina de los beneficiarios de su crédito aparecen desde representantes de la nobleza local, regidores y canónigos hasta zapateros y sacristanes, pasando por escribanos, médicos, oficiales de la Inquisición, herreros o labradores.

La imagen se repite como un cliché: un cofre con llave junto a un mueble escritorio esta vez en el dormitorio, otras en el estudio. En el primero, dinero en efectivo, cerca de medio millón de maravedís en doblones, reales de plata y moneda de vellón. En el segundo, cuidadosamente archivadas, las escrituras de censo y obligación, cédulas y libranzas que avalan sus derechos como acreedor. Los censos perpetuos, de incluirlos en el cómputo de instrumentos de crédito, no representarían sino el $2 \%$ del total, tratándose en cualquier caso de escrituras transmitidas por herencia generalmente. Los censos al quitar, en cambio, son cerca de la tercera parte del número de deudas (32\%) y más de tres cuartas partes (77,5\%) del capital prestado. En las cédulas y letras de cambio abundan los nombres de parientes y compañeros de cabildo. Ya vimos, además, que la libranza fue un instrumento recurrente entre prebendados, tanto para la concesión como para la devolución del capital. Así, cuando el canónigo don Alonso Venegas de Cañaveral solicitó a Juan Pérez Mohedano de Valenzuela 700 reales prestados, éste se los hizo llegar por medio de Juan Evialches Freijo, canónigo de Santiago. Posteriormente, Venegas de Cañaveral devolvería el dinero por medio de otra libranza sobre Alonso Suárez, mayordomo del cabildo. También aparecen entre sus papeles algunas prendas empeñadas, como un arpa de oro de Pedro de Pineda, un paño colorado y un coleto del capataz Juan Sánchez, o una joya en forma de lagartija de Francisco de la Fuente. Finalmente, por el libro de cuentas sobre el escritorio, toda una serie de deudas de las que no consta instrumento alguno, sino tan sólo el asiento por escrito de mano del prebendado o su mayordomo. Son en su mayoría pequeños préstamos que no suelen superar los doscientos ni aun los cien reales, concedidos a menudo a vecinos de Pedroche, su localidad natal.

Al igual que en éste en todos los demás ejemplos allegados nos encontramos por regla general con unos patrones en la política de préstamos. Responde como era de esperar, y esto es más claramente visible fuera del área urbana cordobesa, a los circuitos de redistribución de la riqueza en que se inserta cada prebendado. No es casual y sobra decirlo que parte importante de su actividad económica se volcara en ámbitos geográficos concretos. Haya quedado constancia documental o no de ellos, no cabe dudar de la existencia de vínculos personales de algún tipo, ya fueran de tipo familiar o clientelar, por naturaleza o derivados de la propia carrera eclesiástica. 
También hemos de tener en cuenta la otra cara de este tipo de actividades. No siempre era fácil hacer pagar con puntualidad ni aun sin ella a poderosos nobles endeudados o a herederos que se encontraban con un patrimonio recién adquirido y lleno de cargas. Agotadas todas las vías, los capitulares no dudaban, desde luego, en recurrir a la justicia si era necesario.

Por motivo de impago de un censo de 10.000 reales interpuso querella en 1610 el racionero Rodrigo Muñoz Bermúdez contra doña Mariana de Figueroa, hija y heredera de don Alonso de Figueroa. La demandada alegaba que aunque su firma constaba en la escritura de censo, había de darse por nula,

porque al tiempo del otorgamiento de ella mi parte era menor de veinte y cinco años y aun de diez y seis, y fue inducida y atemorizada por don Alonso de Figueroa, su padre, el cual le mandó que la otorgase y mi parte no lo pudo contradecir ni tuvo libertad para ello, respecto de su menor hedad y de la terribleza de condición del dicho su padre, al cual si le resistiera u dijera alguna cosa la maltratara, de manera que fue el temor justísimo que mi parte tuvo para no osarlo contradecir ${ }^{71}$.

Las alegaciones no parecen haber servido de mucho para frenar el proceso, pues se ordenó la realización de un inventario y tasación de los bienes de cara a su venta en almoneda.

Mayores problemas para cobrar tuvo el racionero Juan Mellado de Almagro, cuyo pleito se prolongó de 1686 a 1688, aunque finalmente también saldría con la suya. De una parte, las trabas le vinieron por la renuencia de los oficiales de Antequera a meter mano a las propiedades del vecino deudor, el Conde de Mollina, con lo que los sucesivos envíos de agentes fueron en vano, «porque algunas veces la justicia de dicha ciudad le han denegado el cumplimiento, otras no ha querido ningún escribano de ella asistir a los ejecutores... $\rangle^{72}$. De otra parte, el Conde adeudaba también al Consejo de Hacienda los 750 ducados de la media anata de su título, por lo que desde Madrid se había decretado el embargo de sus bienes y la prioridad en el cobro, debiendo esperar los demás acreedores. En este caso se trataba de un censo de 33.000 reales de principal.

Ciertamente, muchos de estos préstamos se hacían a parientes y amigos, a quienes no se exigía el pago durante años. Llegado el caso, se contaba con la cantidad adeudada como parte del legado testamentario. Entre otros individuos, el cobro de los réditos no era tan importante como el vínculo creado mediante la concesión de los créditos y las posibilidades que ofrecía. Puesto que la actividad de préstamo no siem-

71 ARChGr, Pleitos, leg. 93, pieza 5, s.f.

72 ARChGr, Pleitos, leg. 850, pieza 10, s.f. 
pre estuvo motivada en exclusiva por el estricto cálculo financiero o la búsqueda del beneficio monetario, la existencia de una bolsa de deuda de difícil cobro entraba dentro de los cálculos ordinarios.

Si no de todos los préstamos cabe deducir un aumento real de los ingresos en forma de intereses, toda actuación en esta línea puede ser indicativa del establecimiento o el refuerzo de lazos sociales, por no hablar de la función del prebendado como fuente de crédito en el seno de la parentela. No hay que olvidar a este respecto que, a fin de cuentas, las actividades crediticias fueron un mecanismo de redistribución de la riqueza a distintos niveles y, por consiguiente, herramienta social utilísima en manos de un grupo humano que actuó desde la perspectiva antropológica como auténtico redistribuidor. Claro está que, «los redistribuidores que se recompensan a sí mismos en primer lugar y en mayor medida siempre han precisado echar mano de ideologías y rituales para legitimar su apropiación de la riqueza social» ${ }^{73}$, pero otro habrá de ser el espacio para el análisis de tales construcciones culturales, de la imagen legitimadora que ofrecía la institución catedralicia.

\section{La administración particular}

Cabe decir por consiguiente que los prebendados miraron muy mucho por sus finanzas particulares, y su gestión se demostró en líneas generales cuidadosa. El mantenimiento de un libro de caja o de cuentas en la casa fue en este sentido una constante ${ }^{74}$. En él se recogía absolutamente todo, desde los gastos de vino y aceite a los aguinaldos navideños a criados y parientes, pasando por el pago de deudas y cargas fiscales, por sistema de partida doble, de ahí que también se denomine libro de cargos y descargos. En los casos de mayor envergadura, como el del citado deán don Juan de Córdoba, era corriente incluso la existencia de varios libros secundarios por materias como plata, despensa o bodega, a cargo de los criados responsables de tales menesteres. Estos libros eran luego supervisados por el mayordomo, quien centralizaba todo en una única

73 M. HARRIS, Nuestra especie, Madrid, 1989, p. 332. En esta misma línea se expresa Pedro Quintana sobre los capitulares canarios: «la acumulación de riquezas por parte de un mínimo sector social era justificada como un don de Dios frente a la resignación del resto de la sociedad, subyugada por la ideología imperante y agradecida a la limosna que caía de la mano del poderoso». QUINTANA ANDRÉS, P. C.: A Dios rogando..., p. 306.

74 Las referencias a su existencia aparecen en las fuentes a lo largo de todo el período, desde el siglo XVI (don Juan de Córdoba, Fernando Mohedano de Saavedra, Juan Pérez Mohedano de Valenzuela, don Antonio de Corral, don Diego de Córdoba y Mendoza... AHPCo, leg. 12.853-P, fols. 613r. y ss., especialmente 653v.-654v.; leg. 12.406-P, fols. 315r.-330v.; leg. 13.248-P, fol. 674v.; leg. 10.294-P, s.f., leg. 10.296-P, s.f.), al XVIII (don Juan de Ayuda Medina, don Fernando José de Molina y Sandoval, don Juan de Navas y Recio... AHPCo, leg. 16.029-P, fol. 994v. y ss.; leg. 8.591-P, fol. 139v., y 229r.-236r.). 
administración recogida en el libro principal, que era el que se presentaba al amo para su aprobación. Al ser documentación privada y de vida útil corta, su conservación resulta rarísima, frente a los relativamente abundantes ajustes de cuentas protocolizados con los administradores de frutos de las prebendas.

Por fortuna, sucedía en ciertas ocasiones que el prebendado se veía forzado a pasar largas temporadas fuera de casa y, a su regreso, no fiaba tanto en el buen manejo de toda la hacienda durante su ausencia como para excusar al mayordomo de una pormenorizada rendición de cuentas ante escribano público. Cuando así ha ocurrido, tenemos en nuestras manos un reflejo fidedigno de dichos libros de cuentas, un documento en definitiva de enorme valor para la reconstrucción de las economías domésticas canonicales. Es lo que hicieron por ejemplo el racionero Juan de Riaza en 1584, tras una de sus estancias en Granada como procurador del cabildo ante la chancillería, o el arcediano don Andrés de Rueda, quien, imposibilitado de fiscalizar y aprobar directamente las cuentas de su mayordomo Antonio Ruiz de Rebolledo, por la necesidad de permanecer en la corte, contrató entre 1639 y 1641 a Bartolomé de Gálvez Valverde a modo de auditor de los libros fenecidos de cada año ${ }^{75}$. En la siguiente tabla (véase cuadro 1 a continuación) se ofrece una síntesis de los balances de gastos e ingresos presentados para los años 1638 y 1639.

Cuadro 1

\begin{tabular}{|c|c|}
\hline \multicolumn{2}{|c|}{ Cuentas de la hacienda de don Andrés de Rueda } \\
\hline Año 1638 & Año 1639 \\
\hline \multicolumn{2}{|l|}{ Cargo (ingresos) } \\
\hline $\begin{array}{r}+2.264,92 \text { fanegas de trigo } \\
+1.091,18 \text { fanegas de cebada } \\
+110 \text { pares de gallinas } \\
+91.648,17 \text { reales }\end{array}$ & $\begin{array}{r}+3.188,79 \text { fanegas de trigo } \\
+1.453,68 \text { fanegas de cebada } \\
+268 \text { pares de gallinas } \\
+109.670,82 \text { reales }\end{array}$ \\
\hline \multicolumn{2}{|l|}{ Descargo (gastos) } \\
\hline $\begin{array}{r}-2.042,94 \text { fanegas de trigo } \\
-1.020,33 \text { fanegas de cebada } \\
-110 \text { pares de gallinas } \\
-97.845,23 \text { reales }\end{array}$ & $\begin{array}{r}-2.082,37 \text { fanegas de trigo } \\
-1.453,54 \text { fanegas de cebada } \\
-105 \text { pares de gallinas } \\
-94.289,44 \text { reales }\end{array}$ \\
\hline \multicolumn{2}{|l|}{ Alcance (saldo) } \\
\hline $\begin{array}{r}221,98 \text { fanegas de trigo } \\
70,85 \text { fanegas de cebada } \\
0 \text { pares de gallinas } \\
-6.197,06 \text { reales }\end{array}$ & $\begin{array}{r}1.106,42 \text { fanegas de trigo } \\
0,14 \text { fanegas de cebada } \\
163 \text { pares de gallinas } \\
15.381,38 \text { reales }\end{array}$ \\
\hline
\end{tabular}

75 Para no multiplicar las notas, en adelante me remito para cualquier referencia que haga a estas últimas cuentas a AHPCo, leg. 11.758-P, fols. 535r.-630r. 
Ruiz de Rebolledo recogía en un libro borrador todas las operaciones relativas a los gastos e ingresos reflejados en los libros que de cada materia llevaban él o el despensero, ayudados por su sobrino. Finalmente todos los movimientos eran anotados en limpio en el libro de caja, clasificados según su tipología y ordenados por asientos. Éstos se numeraban y el libro se foliaba, de manera que luego fuera más fácil remitir a una partida concreta.

Se trata como en el resto de casos estudiados de una administración compleja, pero muy racional, que atendía siempre a tres cuentas independientes, denominadas pan, gallinas y maravedís por la unidad de cuenta de cada una de ellas (fanegas de trigo y cebada, pares de gallinas vivas y dinero en metálico), todo por partida doble. En las cuentas de pan y de gallinas, el cargo equivale a lo ingresado por el eclesiástico, mientras el descargo cubre tanto lo consumido como lo prestado, pagado o vendido en estas especies. La mayor parte del grano del cargo de un año se vendía entre enero y junio del año próximo a la búsqueda de mayores beneficios, por lo que en las siguientes cuentas aparecía descargado en el pan y cargado en los maravedís con indicación de los precios obtenidos por fanega. Al ser la variación de los mismos bastante grande, dependiendo de dónde, cómo y cuándo se vendiera, es prácticamente imposible realizar una reducción exacta de los ingresos a moneda de cuenta. En los cargos de maravedís de la hacienda del arcediano Rueda Rico, puede observarse que en las ventas realizadas en 1638 la fanega de trigo osciló entre los 8,5 y los 18 reales y la de cebada entre los 4 y los 10 reales. El propio mayordomo especifica a veces las causas: los precios más bajos responden a situaciones en que urgió vender para desalojar las existencias de mayor antigüedad de los alhoríes ante la necesidad de guardar nuevas remesas o se prefirió vender en el momento y lugar de la cosecha, los más altos a grano fiado en los llamados meses mayores.

Tal cual queda patente en la anterior tabla, la producción agrícola condicionaba enormemente las finanzas canonicales. Una buena cosecha podía suponer la diferencia entre un saldo positivo o negativo en un plazo inmediato, pero tanto el sistema de administración como una cierta diversificación de las fuentes de ingreso en el mejor de los casos permitieron mayoritariamente el mantenimiento de los mismos niveles de gasto. Cada cierto tiempo, por otra parte, se podía contar con un aporte extra procedente del reintegro de una parte del patrimonio en forma de deuda ${ }^{76}$. No dejemos tampoco que los saldos negativos nos engañen: 1638 no fue un año catastrófico para el arcediano Rueda, sencillamente se sumaron a una cosecha no muy abundante unos gastos algo mayores. Ello no le significó la pérdida de un maravedí. Un

76 La cuantía acumulada a favor de don Andrés de Rueda en 1638 en forma de deuda sin cobrar por distintos conceptos ascendía a 1.652.114,70 maravedís (48.591,61 reales). En 1639 se había rebajado a 1.539.662 maravedís $(45.284,17$ reales). 
año próspero como 1639 no sólo dejó saldadas las cuentas sino que le reportó buenos beneficios ${ }^{77}$. Haré para mostrarlo más a las claras un rápido ejercicio de cálculo especulativo, sin mayor valor que éste, sobre el balance de cuentas de estos dos años. Transformados el pan y las gallinas no vendidas a reales ${ }^{78}$ y sumados a los ingresos en metálico, el saldo para 1638 resultaría negativo en $2.997,21$ reales, pero los beneficios netos del siguiente año ascenderían a nada menos que 30.353,47 reales. Si el balance de este arcediano, tras costear sus ingresos todas las cargas más los gastos derivados del mantenimiento de un estilo de vida acorde a su posición social, arrojaba cifras de ahorro que rondan los dos y tres mil ducados algunos años, sin lugar a dudas una cuantiosa ganancia, no puede por menos que concluirse que estaba capacitado para afrontar enormes esfuerzos financieros. A partir de entonces, don Andrés de Rueda engrosaría aún más sus rentas gracias a los emolumentos que comenzó a percibir tras ser nombrado consejero de la Suprema.

En cuanto a las cuentas que de la hacienda del racionero Juan de Riaza dio su administrador, el capellán Nicolás Rodríguez, se conserva el documento original conservado en el archivo privado del racionero, hoy en la Sección Nobleza de Toledo ${ }^{79}$. Cierto que las cifras podrán no resultar tan llamativas como en el caso anterior, tratamos justamente con el extremo opuesto en la jerarquía capitular al fin y al cabo, pero el precioso detallismo de la fuente no queda aquí reflejado. Aunque anecdótico, es indicativo de una minuciosa gestión económica el prorrateo de lo pagado de más y lo cobrado de menos por los diez días de octubre suprimidos con la reforma del calendario gregoriano de 1582. A continuación se muestra gráficamente (véase gráfico 1) lo que representaron porcentualmente cada una de las fuentes de ingreso. Como se verá, un $13 \%$ de los ingresos de ese año fueron beneficios líquidos del año anterior. La explotación de fincas rústicas y urbanas de su propiedad supuso un $16 \%$. La parte del león, no obstante, fueron como en casi todos los casos las rentas derivadas de la mesa capitular. Por lo demás, poco más cabe glosar el gráfico, que puede ejemplificar a la perfección todo lo dicho hasta ahora sobre las finanzas particulares en el seno de la institución catedralicia.

77 Un promedio entre ambos extremos debió de ser el saldo de 1637, bastante ajustado. Una vez descargados de los ingresos todos los gastos del año quedó un beneficio neto de 7.114,50 reales, 0,21 fanegas de trigo y 1,34 fanegas de cebada para las arcas del arcediano.

78 Tomo para el par de gallinas el mismo precio que las vendidas y cargadas en la cuenta de maravedís, esto es a 7 reales. Como multiplicador para la fanega de grano tomo sencillamente el promedio de todos los precios de venta de 1638: 12,5 reales para el trigo y 6 reales la cebada. 


\section{Gráfico 1}

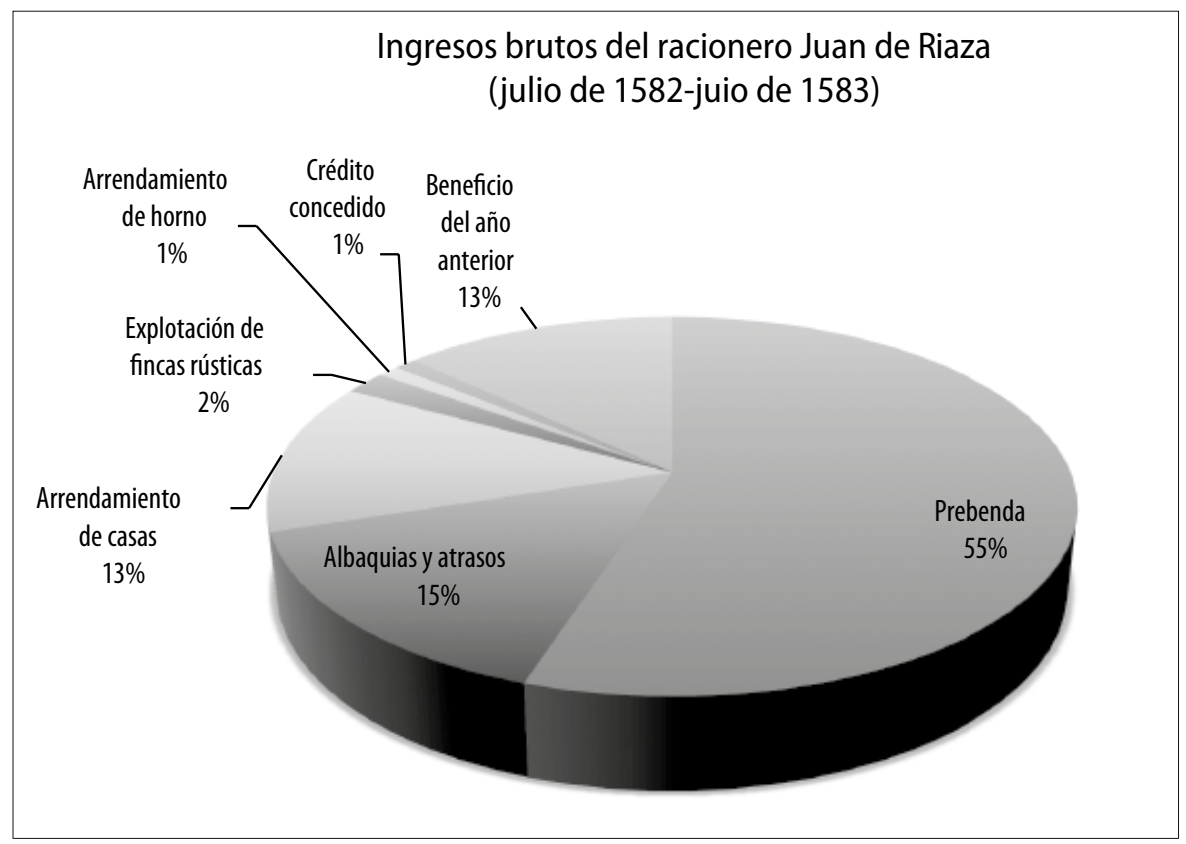

Fuente: SN, Luque, caja 124, doc. 17. Elaboración propia.

\section{La gestión económica de terceros como fuente de ingresos}

Las especiales dotes contables y financieras de algunos clérigos los llevaron a ejercer en el ámbito público o privado como gestores, administradores, contadores, auditores, etc. Muchos actuaron de manera periódica o esporádica como arrendadores y administradores de rentas eclesiásticas: don Pedro González Guijelmo administraba los frutos de la prestamera de Iznájar en nombre de don Jerónimo de Valdenebro, fiscal del Santo Oficio de Valladolid ${ }^{80}$, don Diego Fernández de Soto se encargaba de gestionar el cobro de varios beneficios de la diócesis para clérigos residentes fuera de ella... ${ }^{81}$

79 Las guardas aún conservan la anotación manuscrita de Riaza: «Las quentas sigundas que tomé de mi hazienda a el señor Nicolás Rodríguez en 15 de hebrero de 1584 años». SN, Luque, caja 124, doc. 17, fol. $25 \mathrm{r}$.

80 AHPCo, leg. 11.766-P, fols. 1214r-v.

81 Como el beneficio del Puente de Alcolea de Francisco Ruiz de la Viñuela, clérigo de Burgos, los beneficios de don Antonio de Gamarra, canónigo de Vitoria, o del maestrescuela de Valladolid, por ejemplo (AHPCo, leg. 11.765-P, 11r.; leg. 11.762-P, fols. 904r.-v.; leg. 11.758-P, fol. 1.022r.). 
Mas quien gozaba de aptitudes o sentía inclinación hacia esta clase de actividades, solía explotarlo de forma profesional y en cuantos negocios le sugiriera la oportunidad o le consiguieran sus relaciones dentro y fuera de la catedral. Algunos personajes recrean esto de modo bastante ilustrativo. El racionero Martín Fernández de Zárate simultaneó la administración del Seminario de San Pelagio con la de haciendas de canónigos como Alonso de Buitrago o don Alonso Venegas de Cañaveral. Parejo es el caso del racionero don Francisco de Salinas Medinilla, contador y tesorero del obispo fray Diego de Mardones a la vez que administrador de varios beneficios eclesiásticos, como los puestos en sus manos por la princesa de Mélito en nombre de su hijo menor de edad, don Diego de Silva y Guzmán, propietario de la abadía de Salas, los beneficios de Castro y Espejo o la prestamera de la parroquia de San Miguel de Córdoba. El prebendado, a sueldo de esta señora, recibía sus órdenes directas o intercambiaba con ella pareceres en materia de especulación cerealística ${ }^{82}$. El canónigo Juan de Arévalo, contador del Santo Oficio, fue asimismo administrador de confianza del marqués de Guadalcázar en Córdoba durante los años en que éste gobernó el virreinato de Nueva España. En su nombre vendía grano, alquilaba inmuebles, cobraba deudas o llevaba las cuentas y pagos de la obra de un nuevo hospital en la villa señorial del marqués ${ }^{83}$, quien desde México le pagaba por medio de libranzas en mercaderes y agentes bancarios de Cádiz o Sevilla ${ }^{84}$. Algunos de estos clérigos podrían equipararse a los preti economi italianos ${ }^{85}$.

Hubo también quien adquirió o heredó oficios públicos perpetuados que eran dados en arrendamiento, o bien él mismo actuaba como arrendador ${ }^{86}$. Fue una fuente de ingresos no mayoritaria, pero reseñable.

82 A fines del invierno de un año de gran crisis como fue 1630, don Francisco de Salinas escribía a uno de sus apoderados para la administración de estos beneficios, advirtiéndole sobre lo decidido por la duquesa de Pastrana: «el trigo no quiere mi señora la Princesa que venda menos de a diez y siete, y quiere se aguarde hasta mayo». SN, Torrelaguna, caja 12, doc. 4.

83 AHPCo, leg. 10.766-P, fols. 36r.-v., 49r.-v., 235r.-236v., 301r., o 401r.-v.

84 Ejemplo de uno de estos pagos son los 3.200 reales que el marqués le libró sobre Clemente de Aguiniga, regidor de Cádiz, el 21 de mayo de 1613, los cuales el canónigo envió a cobrar sin éxito a Juan Díaz, mercader de seda. Al cabo terminó por cobrarlos en Sevilla en 1614, no sin algunos retrasos y problemas, de manos de Antonio María Bucareli y Federico Federíguez (obviamente castellanización de Bucarelli y Federighi, ambos linajes florentinos emparentados y recién asentados en la ciudad andaluza por aquel entonces. $C f$. NÚÑEZ ROLDÁN, F.: "Tres familias florentinas en Sevilla: Federighi, Fantoni y Bucarelli (1570-1625)", en Presencia italiana en Andalucía: siglos XIV-XVII. Actas del III Coloquio Hispano-Italiano, Sevilla, Escuela de Estudios Hispanoamericanos, 1989, pp. 23-50). AHPCo, leg. 10.766-P, fols. 55v.-56r., 287v.-288r. y 378r.

85 DONATI, C.: Ecclesiastici e laici nel Trentino del Settecento (1748-1763), Roma, Istituto storico italiano per l'età moderna e contemporanea, 1975, pp. 24-28.

86 La mayoría de estos casos se dan ya en el siglo XVIII, como el de don Fernando José de Molina y Sandoval, propietario de un oficio de corredor de lonja (AHPCo, leg. 8.591-P, fols. 138r.-v.), o el de don Juan Benito de Samaniego, arrendador de un oficio de procurador del número de Córdoba por 550 
Dentro de esta esfera de la gestión, otro tipo de negocio algo más extendido entre las filas cabildalicias fue el de la tramitación de letras apostólicas de todo tipo: indulgencias, dispensas matrimoniales, de incompatibilidad canónica, de edad, órdenes o legitimidad, bulas de coadjutoría y de resigna, de permuta, de supervivencia, de regreso o de reserva, para la legitimación de hijos sacrílegos, la erección de capellanías y monasterios o la secularización personal... la oferta era enorme y la demanda infinita, pero no todos podían permitirse viajar hasta Roma a la búsqueda de la obtención del deseado u obligado documento pontificio. Surgen aquí figuras como el canónigo Andrés Vela, los racioneros Miguel Bermúdez, Rodrigo Muñoz Bermúdez, Andrés Chirino de Morales, Diego Belloso de Vargas y todo un enjambre de clérigos dispuestos a solucionar los engorrosos problemas de la expedición, poniendo a disposición del necesitado su saber hacer y contactos en la Dataría, a cambio de dinero. A veces nos topamos en este mundillo con los mismos hombres que ejercen como administradores de rentas señoriales o eclesiásticas, pero si entre aquéllos pesaban los conocimientos contables, recaudatorios y administrativos, para estos menesteres son de más utilidad el bagaje jurídico y la experiencia de la práctica burocrática romana.

Como en lo relativo al préstamo a interés, es muy difícil rastrear la ganancia que podía suponer esta granjería de asuntos espirituales. Si en el primer caso se huía del fantasma condenado de la usura, en el segundo lo que había que maquillar era la imagen de la simonía. En uno y otro la realidad se veía sustituida por manidas expresiones de servicial obsequio o amistad. Habida cuenta de los miles de ducados que podían pasar en un año por las manos de los dedicados a este mercadeo, un corto porcentaje de beneficios lo haría ya de por sí bastante atractivo. Habremos de dejar empero este tema, tan amplio y complejo que desborda los límites de este artículo, para otra ocasión.

\section{A modo de conclusión}

A partir de lo expuesto y obviadas las puntuales excepciones, no se sostiene la idea de unos capitulares limitados al cobro de su prebenda como agentes económicos pasivos. Tratamos con un grupo dinámico, independientemente del carácter

reales anuales propiedad de su hermana (AHPCo, leg. 13.054-P, fol. 51r.). Don José de Navas Sanllorente poseía a mediados del XVIII un oficio de escribano del número y otro de alcaide de las aduanas de la ciudad. La utilidad de ambos se estimó para la realización del Catastro de Ensenada en 600 reales y 588 reales y 8 maravedís anuales respectivamente (AHPCo, Catastro de Ensenada, libro 323, fols. 430r.438v.). 
conservador de sus inversiones, y dentro del marco de la evolución económica de entorno (en el caso de la ciudad y del reino de Córdoba, marcada en líneas generales por dos grandes fases de signo contrario: un crecimiento sostenido desde principios del XVI, bien documentado para los años 1530-1580, y el imparable declinar al que dejarían paso las crisis de 1582 y 1601 en los siglos posteriores ${ }^{87}$ ).

Así pues, aunque períodos concretos puedan resultar más interesantes en valores absolutos, comparativamente el clero catedralicio se mantuvo a lo largo de todo el Antiguo Régimen como parte de la oligarquía económica local merced a sus fuentes de ingresos, a su potencial capacidad de crédito y liquidez, así como a unas estrategias financieras eficaces, tan sólo lastradas aparentemente por las de índole familiar y el dispendio. Pero no hemos de olvidar que al fin y al cabo eran estas ambiciones de largo alcance el primer y último motor de todo ello, y no el mantenimiento de unas cuentas saneadas. En esta dinámica, el gasto suntuario ha de ser entendido como una táctica social más. Los procesos de endeudamiento sistemático de individuos sin una aparente necesidad personal de hacerlo sólo se explican dentro de ese marco de obligaciones y solidaridades forzosas, pero completamente asumidas.

Hay que tener presente que estamos ante un conjunto de cientos de individuos de extracción social, circunstancias, inteligencias y personalidades diferentes. De este hecho se deriva la dificultad de trazar rasgos comunes en cuanto a los comportamientos económicos, más allá de la existencia obvia de individualidades excepcionales o de un marco cronológico extenso como el de este estudio. Lo excepcional puede ser sumamente ilustrativo de la norma y un examen en la larga duración aporta la perspectiva necesaria para observar pautas y constantes, en éste como en otros aspectos analizados. Patrones hubo y se mantuvieron a lo largo de las décadas. El atesoramiento, la inversión y el gasto suntuario no fueron disonantes, por otra parte, sino que coexistieron al servicio de las estrategias sociales de cada individuo, familia y coyuntura.

Estas conclusiones, sobra decirlo, no son exclusivas del cabildo cordobés, sino perfectamente extrapolables al conjunto del territorio hispano, salvadas las peculiaridades de la vida económica de cada lugar y mesa. Ciñéndonos a la principal fuente de ingresos y común denominador, el potencial de una prebenda en Sevilla no era comparable al de otra en Lérida, aunque no hemos de olvidar que tampoco el nivel de

87 FORTEA, J. I.: Córdoba en el siglo XVI: las bases demográficas y económicas de una expansión urbana, Córdoba, Monte de Piedad y Caja de Ahorros de Córdoba, 1981, pp. 114-171 (la tesis en su totalidad se centra realmente en el análisis de esta realidad). Ya antes Ramón Carande calculaba el descenso del vecindario cordobés de los 33.060 habitantes de 1530 a los 31.285 de 1594. CARANDE, R.: Carlos Vy sus banqueros, Barcelona, Crítica, 2004, p. 13. 
vida en una y otra ciudad lo era ${ }^{88}$. Las disimetrías refuerzan, por añadidura el valor de nuestro caso de estudio, media natural entre los distintos puntos peninsulares.

Ni la búsqueda de inversiones seguras ni las jeremiadas puntuales deberían impedirnos ser conscientes del primordial rasgo de las finanzas de este grupo de eclesiásticos: su indiscutible capacidad de respuesta a las necesidades de gasto que conllevaban los objetivos sociales, tanto en sus personas como, sobre todo, en sus parientes.

88 DOMÍNGUEZ ORTIZ, A.: Las clases privilegiadas en el Antiguo Régimen, Madrid, Istmo, 1985, pp. 240-241. 